\title{
Keepin' It Real (Respectable) in 2008: Barack Obama's Music Strategy and the Formation of Presidential Identity
}

\author{
DANA GORZELANY-MOSTAK
}

\begin{abstract}
From the earliest elections with popular participation to the present day, American presidential candidates have harnessed music's connotative potential and affective properties in a variety of campaign contexts. But in a corporatized electoral landscape where the fields of politics and popular culture are inextricably intertwined, and every aspect of the candidate's public and private life is subjected to intense scrutiny enabled by the emergence of Web 2.0 technologies, nontraditional texts (such as music) play an increasingly significant role in candidate identity formation. Adding to recent work that explores the aesthetic and social dimensions of newly composed campaign music and its cultural currency, this essay turns a critical lens toward preexisting music and its impact on campaign discourses during Barack Obama's 2008 presidential primary campaign. I investigate three components of Obama's soundscape: 1) his engagement with hip hop-its artists, audiences, and values; 2) the intersections between his professed musical tastes and his complex biography; and 3) the playlists he used at campaign rallies, and the factors that allowed this soundtrack to solidify his own identity as candidate as well as forge alliances with women voters and black voters. Ultimately, cultural and musical analyses reveal how Obama's music strategy allowed him to project a black identity that was both "real" and "respectable."
\end{abstract}

\section{Taking the Dais}

Politicians often reveal their musical tastes in interviews or through their selection of a campaign playlist. Jimmy Carter tuned in to Bob Dylan during his downtime, Ronald Reagan capitalized on the popularity of Lee Greenwood's "God Bless the U.S.A." for his 1984 reelection bid, and George W. Bush's "iPod One" contained country music and classic rock with "a little bit of hard core and honky tonk," a playlist Rolling Stone journalist Joe Levy called safe, reliable, and loving. ${ }^{1}$ When he was not wielding his saxophone on late night television, die-hard Elvis fan Bill Clinton frequently approached or exited the dais to Fleetwood Mac's 1977 hit "Don't Stop." The Arkansas native also featured a throwback playlist of classics by artists such as the Beatles, Elvis, and Mary Wells at his 1992 rallies, and in choosing a nostalgic soundscape for his campaign, he affirmed his pop-culture savvy and hip persona as well as established common ground with his baby boomer compatriots.

Earlier versions of this essay were presented at meetings of the Society for American Music in Cincinnati, OH (2011), the Canadian University Music Society in Waterloo, ON (2012), and the International Association for the Study of Popular Music-Canada in Wolfville, NS (2012). I would like to thank Lisa Barg, David Brackett, Justin Burton, Remi Chiu, Travis L. Gosa, Eric Hung, Neil Lerner, Sharon Mirchandani, Erik Nielson, Fred Maus, Felicia Miyakawa, and Lloyd Whitesell for their valuable feedback on drafts of this essay.

1 "Bush's iPod Reveals Music Tastes," BBC News, 13 April 2005, http://news.bbc.co.uk/2/hi/ 4435639.stm. 
Harnessing the power of YouTube and the cultural phenomenon of reality talent contests, 2008 candidate Hillary Clinton demonstrated digital proficiency and her own pop culture cred by launching a "Choose Our Campaign Song" contest via video announcement and leaving the selection of her one official campaign song up to her constituents. ${ }^{2}$

Although presidential candidates from the 1840s to roughly the 1970s typically relied on newly written, candidate-specific texts set to well-known melodies or newly composed music for their public appearances, between the campaigns of Clinton and Clinton, unaltered, preexisting popular songs such as "Don't Stop" which already circulated on record, radio, film, or television-became the gold standard for American presidential campaigns. ${ }^{3}$ Rallies, conventions, fundraising concerts, and more recently, candidate webpages and YouTube have featured preexisting music, creating a diverse and multivalent soundscape that infuses old music with new political and cultural significance. As popular texts, preexisting songs hold the potential to signify on multiple levels; they offer up rich histories, associated cultural texts, a complex web of intra- and extra-musical connotations, a body of criticism, and audiences already culturally invested in them. And as Richard Middleton suggests, discourses about the songs, their representative genres, and artists (who maintain their own histories, star personas, political orientations, and fan bases) can be equally implicated in the constitution of musical meaning. ${ }^{4}$ As I suggested with the Clintons and Bush, preexisting songs project a cluster of associations onto a politician, thus contributing to their brand, or, their presidentiality, to use the term favored by Shawn J. Parry-Giles and Trevor Parry-Giles. ${ }^{5}$

Under most circumstances, politicians' personal musical tastes or rally playlists on the campaign trail would not be a source of much controversy or even serious inquiry. But in a corporatized electoral landscape where the fields of politics and popular culture are inextricably intertwined, and every aspect of the candidate's public and private life is subjected to intense scrutiny enabled by the emergence of Web 2.0 technologies, nontraditional texts (such as music) play an increasingly significant role in selling a presidential candidate. During the 2008 presidential primary race, this confluence of political and popular culture was especially apparent in the campaign of newcomer Barack Obama, a candidate whom Naomi

${ }^{2}$ Dana Gorzelany-Mostak, “'I've Got a Little List': Spotifying Mitt Romney and Barack Obama in the 2012 U.S. Presidential Election,” Music \& Politics 9, no. 2 (2015), DOI: http://dx.doi.org/10. 3998/mp.9460447.0009.202.

${ }^{3}$ See Danny O. Crew, Presidential Sheet Music: An Illustrated Catalogue of Published Music Associated with the American Presidency and Those who Sought the Office (Jefferson, NC: McFarland, 2001); and Benjamin S. Schoening and Eric T. Kasper, Don't Stop Thinking About The Music: The Politics of Songs and Musicians in Presidential Campaigns (Lanham, MD: Lexington, 2012).

${ }^{4}$ Richard Middleton, "Locating the Popular Music Text," in Reading Pop: Approaches to Textual Analysis in Popular Music, ed. Richard Middleton (Oxford: Oxford University Press, 2000), 1-19; and Middleton, “From Me To You' Popular Music as Message," in his Studying Popular Music (Milton Keynes: Open University Press, 1990), 172-246.

${ }^{5}$ Shawn J. Parry-Giles and Trevor Parry-Giles, Constructing Clinton: Hyperreality \& Presidential Image-Making in Postmodern Politics (New York: P. Lang, 2002), 1-5. 
Klein later proclaimed the "first U.S. president who is also a superbrand." ${ }^{6}$ The divulgence of musical taste created a potential political minefield for the senator from Illinois. The personal (represented here by music preference) was definitely political. Obama's iPod contents were not just a human-interest story, but also a litmus test to determine his cultural blackness as well as his acceptability as a candidate, even though the public acknowledged the performative dimension of such disclosures.

Taking into consideration the unique challenges that Obama faced due to his multiracial identity and complex personal and political background, and the central role media spectacles played in his image formation, this essay investigates the candidate's 2008 campaign soundscape and the discourses it both reflected and engendered in live and virtual contexts. ${ }^{7}$ I explore three facets of the primary campaign soundscape: 1) the candidate's engagement with hip hop-its artists, audiences, and values; 2) the intersections between his professed music tastes and his complex biography; and 3) the playlists he used at rallies and the factors that allowed this soundtrack to solidify his own identity as candidate as well as forge alliances with women voters and black voters, the two constituencies he needed to win over in order to defeat his Democratic rival, Hillary Clinton. Positioning the existing corpus of work on music and Obama as a launching point, and recent research on the intersections of gender and race identities in American presidential politics as a critical and contextual frame, I show how Obama's music strategy allowed him to project a black identity that was both "real" and "respectable."

\footnotetext{
${ }^{6}$ Naomi Klein, No Logo: 10th anniversary edition (New York: Picador, 2009), xxiii.

${ }^{7}$ In the past seven years, the topic of music and Obama has become fertile ground for scholars in the areas of musicology, media studies, political science, sociology, and Africana studies. Travis L. Gosa investigates the political capital of digital mixtapes with Obama-themed hip hop (called "Obama-Hop") and the campaign-related activities of youth both on and offline. Covering similar terrain as Gosa, Lester Spence examines artists' Obama-inspired tracks and hip hop's potential to engage with black politics, and Erik Nielson, primarily focusing on Young Jeezy's track "My President," investigates the interdependence of Obama and gangsta-type themes in Obama-Hop. Turning to YouTube, Carol Vernallis explores the intertextual and aesthetic dimensions of viral media that emerged during the 2008 campaign. Gosa and Nielson's edited volume, The Hip Hop \& Obama Reader, offers interdisciplinary perspectives on hip hop in the age of Obama, including an outstanding essay by Murray Forman, who investigates how the assertion of musical tastes and age identity allowed the candidate to locate himself in relation to specific classes and constituencies. The conclusions he arrives at are quite similar to my own. Using the concept of collage as a critical lens, Richard Daniel Blim's dissertation addresses campaign advertising and the candidate's own iPod, as well as user-generated, Obama-themed mashups and hip hop offerings. Although we rely on many of the same sources and cultural moments as a starting point for our respective pieces and cover some similar terrain, my work departs from that of Gosa, Nielson, and Spence in that my primary focus lies with preexisting music and its signifying potential, rather than with newly composed music and the cultural currency it brings to campaigns. Gosa and Spence focus on the hip hop community's response to Obama's candidacy, whereas I, like H. Samy Alim and Geneva Smitherman, Michael P. Jeffries, and Forman, am more interested in exploring how the candidate situated himself in relation to this community through the deployment of linguistic and cultural markers of blackness. And rather than focusing on the populist appeal of the candidate's iPod, as thoughtfully explored by Blim and Matthew F. Jordan, I read the candidate's list of favorite songs and rally set lists through the construct of respectability and investigate the reception of his personal tastes and public playlist among specific blocs of voters-women and blacks.
} 


\section{Obama: The Hip Hop President}

Rap and hip hop, Murray Forman argues, are "inextricably entwined with race, cultural politics, ideology, and communication in contemporary America."'8 Politicians such as Ronald Reagan, George H. W. Bush, Bill Clinton, George W. Bush, Dan Quayle, John Kerry, and many others have been the unwitting targets of hip hop verses over the past three decades. However, the relationship between hip hop and electoral politics was an ambivalent one pre-2008, and as Shaun Ossei-Owusu maintains, the skepticism and mistrust directed towards the Obama candidacy by some hip hop devotees might be explained by "hip-hop's historically indignant attitude toward the state." 9 The genre did briefly become a talking point on the campaign trail when in June 1992 presidential hopeful Bill Clinton famously admonished rap artist Sister Souljah (Lisa Williamson) for expressing what he perceived to be black extremist viewpoints in the wake of the Los Angeles riots. In a May 1992 interview with the Washington Post, she stated,

I mean, if black people kill black people every day, why not have a week and kill white people? You understand what I'm saying? In other words, white people, this government and that mayor were well aware of the fact that black people were dying every day in Los Angeles under gang violence. So if you're a gang member and you would normally be killing somebody, why not kill a white person? Do you think that somebody thinks that white people are better, or above dying, when they would kill their own kind? ${ }^{10}$

The candidate sternly criticized her remarks at a meeting of Jesse Jackson's Rainbow Coalition: "Her [Sister Souljah's] comments before and after Los Angeles were filled with a kind of hatred that you do not honor today and tonight. ... If you took the words white and black and reversed them, you might think David Duke was giving that speech." ${ }^{11}$ Affirming her status as a well-informed and respected rap artist and black social activist, Sister Souljah fired back at Clinton (and the Post) for taking her comments out of context and called his genuineness and morality into question. ${ }^{12}$ Indeed this exchange between politician and artist mirrors broader ideological and cultural battles over hip hop's potential transformative power and legitimacy as a form of social critique, as well as substantiates Tricia Rose's claim

${ }^{8}$ Murray Forman, “Conscious Hip-Hop, Change, and the Obama Era," American Studies Journal 54, no. 3 (2010). Following Forman, I use the term "hip hop" to refer to a broad range of cultural practices, including, rapping, deejaying, aerosol art, and breakdancing.

${ }^{9}$ Shaun Ossei-Owusu, "Barack Obama's Anomalous Relationship with the Hip-Hop Community," in The Obama Phenomenon: Toward a Multiracial Democracy, ed. Charles P. Henry, Robert L. Allen, and Robert Chrisman (Urbana: University of Illinois Press, 2011), 224.

${ }^{10}$ Quoted in David Mills, "Sister Souljah's Call to Arms: The Rapper Says the Riots Were Payback. Are You Paying Attention?” Washington Post, 13 May 1992, http://www.washingtonpost.com/wp-dyn/ content/article/2010/03/31/AR2010033101709.html.

${ }^{11}$ In this speech, Clinton also quotes remarks from the opening of Sister Souljah's music video, "The Final Solution: Slavery's Back in Effect," stating that "if there are any good white people, I haven't met them." He then refutes her claim. See "Remarks of Governor Bill Clinton," Rainbow Coalition National Convention, Washington, D.C., 13 June 1992, http://www.ibiblio.org/pub/ academic/political-science/speeches/clinton.dir/c23.txt.

12 "Rap Artist's Response to Clinton Remarks," uploaded 16 June 1992, video clip, C-SPAN Video Library, http://www.c-spanvideo.org/program/26613-1. 
that hip hop functions as a lens through which we gauge the status of race and the state of race relations in America. ${ }^{13}$

Although in the 1990s candidates such as Clinton could safely denounce rap artists without fear of political fallout (these remarks likely increased his stock among white working- and middle-class voters), by the dawn of the twenty-first century, hip hop had transcended racial and economic boundaries and emerged as a global, multi-billion dollar industry with artists and producers who possessed serious political clout. (Despite its global reach and diverse fan base, the genre maintains its symbolic connection with the black underclass, specifically urban youth. ${ }^{14}$ As black politician Adam Clayton Powell IV asserted in 2006, the hip hop generation "dominate[s] everything [culture, music, and economics] except politics, because they generally have not been participating." 15 The industry's engagement with electoral politics reached its height in 2008 with Obama's historic candidacy. Although Russell Simmons (and others in the community) on occasion questioned Obama's ability to effectively address black issues, he and Sean Combs, as well as other hip hop artists, such as Jay Z, Young Jeezy, LL Cool J, Common, Ludacris, and Talib Kweli, endorsed the candidate, performed at rallies and concerts on his behalf, or name-dropped the candidate in their songs. (Travis L. Gosa refers to these tracks and mixtapes as "Obama-Hop.") ${ }^{16}$ Highly visible celebrity artists organized some of these events, but others were the fruits of grassroots community initiatives.

A substantial slice of the "hip hop generation" embraced Obama, but how did Obama feel about hip hop? ${ }^{17}$ Not surprisingly, the question of hip hop's cultural

\footnotetext{
${ }^{13}$ Tricia Rose, The Hip Hop Wars: What We Talk About When We Talk About Hip Hop-And Why It Matters (New York: BasicCivitas, 2008).

${ }^{14}$ For more on twenty-first-century hip hop's engagement with electoral politics, see S. Craig Watkins, Hip Hop Matters: Politics, Pop Culture, and the Struggle for the Soul of a Movement (Boston: Beacon, 2005), 154-56; and Jeffrey O. G. Ogbar, "Message from the Grassroots: Hip Hop Activism, Millennials, and the Race for the White House," Bakari Kitwana and Elizabeth Méndez Berry, "It's Bigger Than Barack: Hip Hop Political Organizing, 2004-2013"; and Travis L. Gosa and Erik Nielson, “There Are No Saviors': An Interview with Kevin Powell” in The Hip Hop \& Obama Reader, ed. Travis L. Gosa and Erik Nielson (Oxford: Oxford University Press, 2015), 31-53, 54-69, and 70-87 respectively.

${ }^{15}$ Quoted in Keli Goff, Party Crashing: How the Hip-Hop Generation Declared Political Independence (New York: BasicCivitas, 2008), 18-19.

${ }^{16}$ Travis L. Gosa, "Not Another Remix: How Obama Became the First Hip-Hop President," Journal of Popular Music Studies 22, no. 4 (2010): 389-415.

${ }^{17}$ Citing historian and journalist James G. Spady's description of hip hop as an "art form/forum," Alim and Smitherman show that the community did not blindly embrace the charismatic candidate simply because he was black and spoke their language, but rather welcomed his candidacy as an opportunity to instigate sophisticated conversations regarding the broader political issues that impact black communities (H. Samy Alim and Geneva Smitherman, “My President's Black, My Lambo's Blue': Hip Hop, Race, and the Culture Wars," in Articulate While Black: Barack Obama, Language, and Race in the U.S. [Oxford: Oxford University Press, 2012], 136-37). Nonetheless, Obama's candidacy was not universally embraced by the hip hop community. Several artists voiced their critique in song (Travis Gosa, “The Audacity of Dope': Rap Music, Race, and the Obama Presidency," in The Iconic Obama, 2007-2009: Essays on Media Representations of the Candidate and New President, ed. Nicholas A. Yanes and Derrais Carter [Jefferson, NC: McFarland, 2012], 85-96). At the 2008 meeting of the National Hip-Hop Political Convention, an organization co-founded by journalist Rosa Clemente, former Black Panther turned activist Dhoruba Bin Wahad cautioned participants to be wary of black
} 
value emerged in several Obama interviews during the 2008 election cycle. The candidate was in a position where he needed to reach out to the hip hop community but was faced with the predicament of engaging with artists and a genre that, in the eyes of many (both black and white), glorified drug culture, urban violence, consumer fetishism, and misogyny. At this time, the conflict and controversy swirled within the hip hop community as well: Whom does hip hop represent? Is it politically relevant?

Obama engaged with hip hop's controversies (what Rose calls the "hip hop wars") when he brought his stance on the genre into the political fray early in 2007. At a fundraising event for the South Carolina Legislative Black Caucus, he criticized radio shock jock Don Imus for referring to the Rutgers University women's basketball team as "nappy-headed hos" during an edition of Imus in the Morning. ${ }^{18}$ In his speech, Obama tendered the following remarks:

We've got to admit to ourselves, that it was not the first time that we heard the word "ho."
Turn on the radio station. There are a whole lot of songs that use the same language. ...
We've been permitting it in our homes, and in our schools and on iPods. ... If it's not good
for Don Imus, I don't know why it's good for us. If we don't like other people to degrade
us, why are we degrading ourselves? ${ }^{19}$

Obama's attack on rap lyrics bears quite a few affinities with Clinton's uninformed indictment of Sister Souljah in 1992. Both candidates direct their remarks to gatherings of black political leaders and both offer universalizing rhetoric that constructs an analogy between the bad behavior of white men and their purported black counterparts: Clinton establishes a parallel between the alleged hate speech of Sister Souljah and that of David Duke, a white nationalist and 1992 Republican presidential candidate. Similarly, Obama establishes a parallel between hip hop artists' degrading language directed towards their sisters and Imus's use of the word "ho" to describe a team of female athletes. In expounding on these equivalents, both candidates fail to acknowledge either the institutionalized inequalities and material realities that fuel hip hop or the role that hyperbole and parody have historically played in various black cultural practices. Shortly after the Caucus Simmons called out the candidate on his indictment of lyrics, claiming, "[w] hat we need to reform is the conditions that create these lyrics. Obama needs to reform the conditions of poverty." 20

In later appearances over the course of the primary campaign, the candidate addressed the issue of lyrics in a more nuanced manner that demonstrated a greater awareness and appreciation of black urban cultures. In a 2008 Black Entertainment

politicians who may only reaffirm the corrupt system of government and institutional hierarchies that perpetuate white supremacy (Ogbar, "Message from the Grassroots," 37-38).

${ }^{18}$ Ryan Chiachiere, "Imus Called Women's Basketball Team 'Nappy-Headed Hos,"” Media Matters, 4 April 2007, http://mediamatters.org/research/2007/04/04/imus-called-womens-basketballteam-nappy-headed/138497.

${ }^{19}$ Jake Tapper and Jerry Tully, "Rap Mogul Takes On Obama,” ABC News, 16 April 2007, http:// abcnews.go.com/GMA/story?id=3045077.

${ }^{20}$ Deborah Solomon, "Hip-Hop Guru," New York Times, 29 April 2007, http://www.nytimes. com/2007/04/29/magazine/29wwlnQ4.t.html?pagewanted=print. 
Television (BET) interview, the candidate attempted to draw a division between hip hop's art and its message:

Honestly, I love the art of hip hop; I don't always love the message of hip hop. There are times where even on the ones that I, even with the artists I named, the artists I love, you know, there is a message that is not only sometimes degrading to women, not only uses the N-word a little too frequently, but also it's something I'm really concerned about, it's always talking about material things. It's always talking about how I can get something, you know, how, you know, I've got more money, more cars, more, and ... I think the potential for them [hip hop artists is] to deliver a message of extraordinary power that gets people thinking. I mean, you know, the thing about hip hop today is, it's smart, I mean, you know a lot, it's insightful, ... the way that they can communicate a complex message in a very short space, is remarkable. ... I understand folks want to be rooted in the community. They want to be down, but what I always say is, is that, you know, hip hop is not just a mirror of what is. It should also be a reflection of what can be. ${ }^{21}$

By privileging the creativity inherent in the process of composition (the art) over the lyrical content (the message), Obama shields himself from critics of the genre, while acknowledging the larger systemic failures that gave rise to the social conditions many hip hop artists explicate in their music. The candidate also makes a plea for art's ethical obligation to envisage a brighter future rather than merely fixate on the present. Rootedness in the community (or keepin' it real), he implies, can be compatible with this imagined future. Moreover, with this statement he refrains from directly criticizing hip hop performers and instead positions these artists and their fan communities as holding the potential to initiate the changes he envisions through their cultural practice. And this vision did come to fruition, albeit for a short period. Gosa and Erik Nielson's research documents "the 'Obamafication of rap': a brief renaissance of socially conscious lyrics and the widespread participation of celebrity rappers in the political process." 22

In March 2008, Obama made a similar comment in an interview with Jann Wenner of Rolling Stone, stating, "I am troubled sometimes by the misogyny and materialism of a lot of rap lyrics, but I think the genius of the art form has shifted the culture and helped to desegregate music. ... It would be nice if I could have my daughters listen to their music without me worrying that they were getting bad images of themselves." 23 Again, the candidate acknowledges the objectionable lyrical content, but uses the word "art" to describe the genre and positions hip hop's "genius" with its ability to promote desegregation. The candidate also plays the role of concerned father, once again praising the art's potential, while implying

21 "USA President Barack Obama Opinion on Hip-Hop \& Rap 2008" [Barack Obama, interview with Jeff Johnson on BET's political special “What's In It For Us?" aired 8 January 2008], uploaded 3 February 2008, video clip, YouTube, http://www.youtube.com/watch?v=pFSVG7jRp_g. Also see "Hip Hop for Obama" [quotes, video footage, and artists' statements], http://www.myspace.com/ hiphopforobama. Transcription by author.

${ }^{22}$ Travis L. Gosa and Erik Nielson, "The State of Hip Hop in the Age of Obama," in The Hip Hop \& Obama Reader, ed. Travis L. Gosa and Erik Nielson (Oxford: Oxford University Press, 2015), 5; and Erik Nielson, "'My President is Black, My Lambo's Blue': The Obamafication of Rap?” Journal of Popular Music Studies 21, no. 4 (December 2009): 344-63.

${ }^{23}$ Jann S. Wenner, “A Conversation with Barack Obama," Rolling Stone 1056/1057, 10 July-24 July 2008, http://www.jannswenner.com/Archives/Barack_Obama.aspx. 
that it still needs to rethink its representation of women. The wise father figure may have also held sway with the hip hoppers themselves. Journalist Gabe Meline writes, "Hip hop can think of Obama as a really, really cool dad. He'll trust hip-hop to be good, and it'll occasionally live up to that trust. It'll do things he disapproves of, but he'll be tolerant, with measured criticism." 24

In assuming the father role, Obama also establishes generational distance, a strategy he deploys in other interviews as well. MTV News asked the candidate how he felt about the hip hop community's excitement over his candidacy in a September 2008 interview. Obama responded by highlighting the gap between his own teenage years and hip hop's infancy, stating "I'm a little older than hip-hop culture. ... I was there at the beginning, but I was already getting older." ${ }^{25} \mathrm{He}$ admitted to shuffling Jay $\mathrm{Z}$ and Kanye on his iPod, but positioned himself as an onlooker who has enjoyed watching "this hip-hop generation" grow. Although Obama does not technically fall into Bakari Kitwana's definition of the hip hop generation, a cohort that includes black Americans born between 1965 and 1984, he did indeed come of age during the era of hip hop. ${ }^{26}$ In any case, hip hop's "really cool dad" chose instead to identify himself as an "old school" guy who prefers the iconic black performers of the 1960s and '70s, a point he articulated quite eloquently in an interview with Hot 97 radio. $^{27}$

Despite the distancing strategies and cautious admission of fandom, the candidate at times subtly hinted that he was indeed "in the know" (although not too much) with regard to hip hop. Obama sauntered onstage to "Crazy in Love," the anthem of hip hop's super couple Beyoncé and Jay Z, during an October 2007 appearance on The Ellen DeGeneres Show. ${ }^{28}$ In the BET interview where he criticized rap's message, he also praised Jay Z's lexical virtuosity because "as Jay would say, 'he's got flow,"” and referred to the mogul's album American Gangster as "tight." ${ }^{29}$ With these accolades, the candidate not only drops his knowledge, he also demonstrates his allegiance to the community by appropriating hip hop vernacular. Although on several occasions the candidate expressed vexation over the artists' penchant for materialism, he praised the business acumen of hip hop producers in the Rolling Stone interview: "I know Jay-Z. I know Ludacris. I know Russell Simmons. I know a bunch of these guys. They are great talents and great businessmen, which is something that doesn't

\footnotetext{
${ }^{24}$ Gabe Meline, "Hip-Hop President: How Will Obama's Presidency Change the Face of HipHop?” Bohemian.com, 31 December 2008, http://www.bohemian.com/northbay/hip-hop-president/ Content?oid $=2173004$.

${ }^{25}$ Sway Calloway, "Barack Obama Gives a Shout-Out to Hip-Hop,” MTV, 27 September 2008, http://www.mtv.com/news/1595820/barack-obama-gives-a-shout-out-to-hip-hop/.

${ }^{26}$ Bakari Kitwana, The Hip Hop Generation: Young Blacks and the Crisis in African American Culture (New York: BasicCivitas, 2002). Kitwana also has a forthcoming volume on hip hop and Obama: Hip-Hop Activism in the Obama Era (Chicago: Third World Press).

${ }^{27}$ Barack Obama interview, Hot 97, New York, June 27, 2007. This interview is cited in Peter Hamby, "Barack Obama Gets Name-Dropped in Hip-Hop," CNN, 17 August 2007, http://www.cnn. com/2007/POLITICS/08/17/obama.hip.hop/index.html.

28 "Barack Obama on Ellen," uploaded 30 October 2007, video clip, YouTube, https://www. youtube.com/watch?v=RsWpvkLCvu4.

29 "USA President Barack Obama Opinion on Hip-Hop \& Rap 2008."
} 
get emphasized enough." 30 Indeed an entrepreneurial spirit and strong work ethic imbues Obama-endorsing artists with an air of respectability. ${ }^{31}$

However, Obama may have wished to retract his praise of Ludacris's business sense shortly after this interview: In late July, the artist released "Politics as Usual," a track that proffered derisive statements towards Hillary Clinton, George W. Bush, and John McCain. Quick to respond, the Obama team deemed the song offensive to not only the individuals directly targeted in its distasteful lyrics, but also "to all of us who are trying to raise our children with the values we hold dear." Once again pinpointing the message rather than the artist, Obama's spokesman Bill Burton stated, "[w]hile Ludacris is a talented individual he should be ashamed of these lyrics." 32 Tricia Rose has called out social critics who take a stance against the sexism in hip hop, yet publically demonstrate their support for the artists who promote it. ${ }^{33}$ Obama might be considered a part of this camp. His contradictory actions irked potential voters, many of whom lodged their complaints online. Giving the candidate's need for youth votes as a reason to keep the artist in his coterie, one retorted, "Obama will publicly condemn Ludacris and privately pat him on the back-then say 'I'm just messing with you man."”34

The candidate did not limit his attempts to frame himself as in the know to interviews or controversies where hip hop momentarily became the topic of focus. In a speech the day after the ABC News debate where, according to Obama, opponent Hillary Clinton played the "textbook Washington game," the younger senator demonstrated his attitude towards her acrimonious barbs by physically brushing the metaphorical dirt off his shoulders. He nonchalantly remarked, "When you're running for the presidency, uh then, you've gotta expect it, uh and, you know, you just gotta kinda let it, you know, you know, that's what ya gotta do." Obama's shoulderbrushing gesture, which blogger Spencer Ackerman cited as "perhaps the coolest subliminal cultural reference in the history of American politics," refers to "Dirt off Your Shoulder," a 2003 Jay Z hit. ${ }^{35}$ With this physical cue-a prime example of the candidate's deft code switching-Obama not only safely pays homage to a hip hop

\footnotetext{
${ }^{30}$ Wenner, "Conversation with Barack Obama."

${ }^{31}$ For another reading on Obama's engagement with hip hop artists, see Michael P. Jeffries, "Where ya at?' Hip-hop's Political Locations in the Obama Era," in The Cambridge Companion to Hip-Hop, ed. Justin A. Williams (Cambridge: Cambridge University Press, 2015), 316-20.

${ }^{32}$ See Ben Smith, "Obama Camp Condemns Song: Ludacris 'Should Be Ashamed," Ben Smith Blog (blog), Politico, 30 July 2008, http://www.politico.com/blogs/bensmith/0708/ Obama 'camp' condemns' song Ludacris' should be ashamed.html\#comments; and Julie Bosman, "The Inner Obama," The Caucus (blog), New York Times, 24 June 2008, http://thecaucus. blogs.nytimes.com/2008/06/24/the-inner-obama/?'php=true\& type=blogs\&gwh= 3EF7CD36484138BE20A4B2BFD948B389\&gwt=pay\& $r=0$.

${ }^{33}$ Rose, Hip Hop Wars, 129.

${ }^{34}$ riley in nc, 30 July 2008 (2:13p.m.) in Smith, "Obama Camp Condemns Song."

${ }^{35}$ For a report on the speech and the gesture, see Ari Melber, "Obama Meets Jay-Z in YouTube Mashup Slamming Clinton \& Debate," Huffington Post, 17 April 2008, http://www.huffingtonpost. com/ari-melber/obama-meets-jay-z-in-yout_b_97342.html. For the speech, see "Obama Gets That Dirt off His Shoulder," uploaded 17 April 2008, video clip, YouTube, http://www.youtube.com/watch? $\mathrm{v}=\mathrm{kzXcNgCr} 0 \mathrm{nk}$. For more on Obama's gesture and Jay Z's song, see Lester K. Spence, "Obama and the Future of Hip-Hop Politics," in Stare in the Darkness: The Limits of Hip-Hop and Black Politics (Minneapolis: University of Minnesota Press, 2011),157-59.
} 


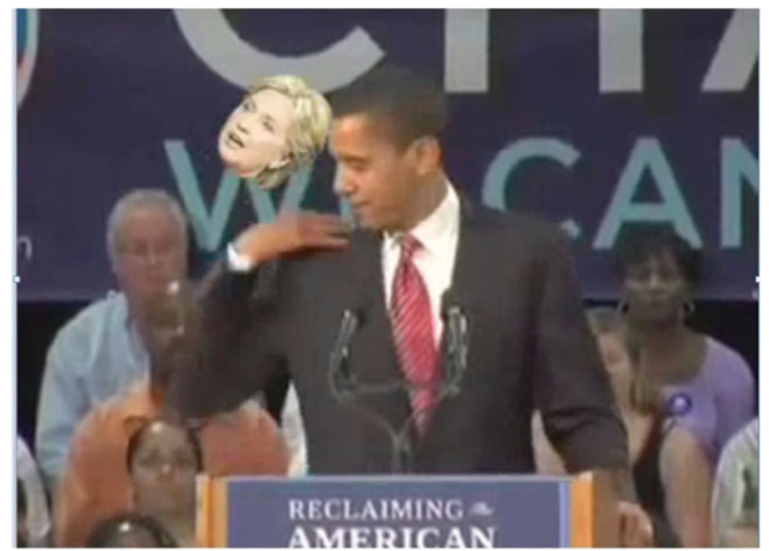

Figure 1. Obama brushes a superimposed image of Hillary Clinton's head from his shoulder. Video still from "Barack Gets That Dirt off His Shoulders." YouTube video uploaded 17 April 2008 by Bill3948, http:// www.youtube.com/watch?v=yel8Ij0AdSc.

standard and its artist, but also forms an alliance with the genre and its community by appropriating and recontextualizing a message in the song that he could agree with - that is, the choice to confront hostility in a non-aggressive manner. ${ }^{36}$ And as the candidate wittily demonstrates, a decision to take the higher ground can be made in the realm of politics, just as it can on the street. By appropriating this symbolic gesture, Obama embraces the respectable side of street culture while he remains removed from the actual language of the song-and rejects the more nefarious aspects of street life: crime and violence. ${ }^{37}$

The candidate delivered this gesture to an audience primarily comprised of young white voters; however, he most likely did so with the knowledge that many of these youngsters came of age around the same time as The Black Album, and that the clip would quickly go viral. ${ }^{38}$ Shortly after the 17 April speech, his campaign placed the video clip on YouTube, and the mashups quickly followed..$^{39}$ In one popular mashup, "Obama Gets That Dirt off His Shoulders," footage from Obama's speech is interspersed with video clips of various detractors criticizing the candidate, while Jay Z's 2003 album serves as the backing track (Figure 1). One clip includes Clinton commenting on Obama's relationship with controversial pastor Jeremiah Wright, and in another, she dismisses some of her opponent's remarks as "elitist" and "out of touch." As Obama reaches the point in his speech with the "dirt off your shoulder" gesture, the music shifts from "Moment of Clarity" to "Dirt off Your Shoulder"

${ }^{36}$ For more on Obama's code-switching strategies see Alim and Smitherman, "My President's Black," and Michael P. Jeffries, "The King's English: Obama, Jay Z, and the Science of Code Switching," in The Hip Hop \& Obama Reader, ed. Travis L. Gosa and Erik Nielson (Oxford: Oxford University Press, 2015), 243-61.

${ }^{37}$ The lyrics in the chorus of Jay Z's song are "you gotta get, that, dirt off your shoulder." Obama states "you gotta" and then completes the phrase with the gesture.

${ }^{38}$ Spence, Stare in the Darkness, 159.

${ }^{39}$ Melber, "Obama Meets Jay-Z." 


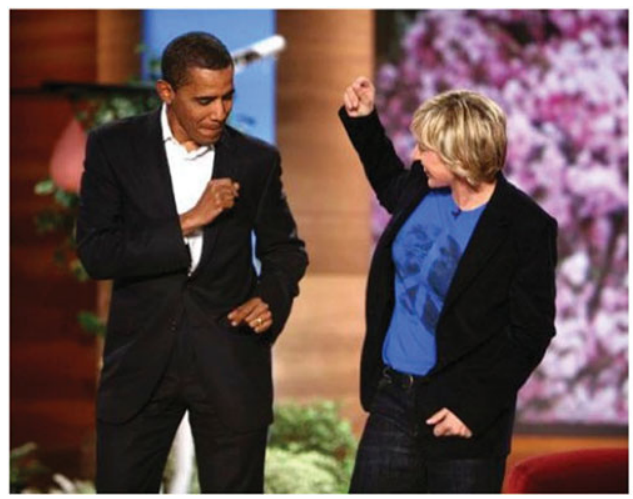

Figure 2a. Obama dances with Ellen DeGeneres. Video still from "Obama Dirt off Your Shoulder Remix." YouTube video uploaded 18 April 2008 by jarts (no longer available).

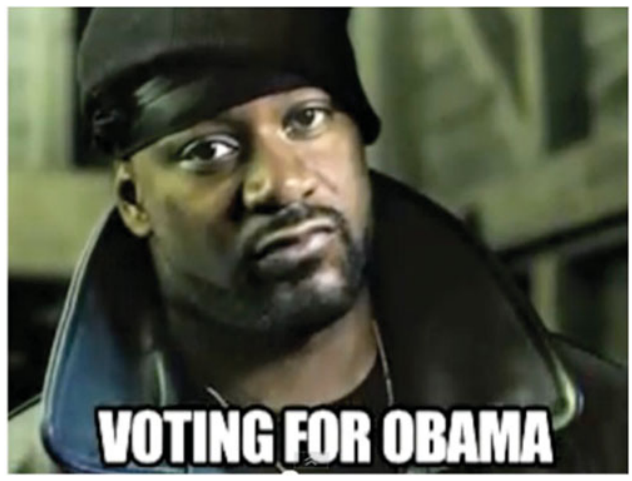

Figure 2b. Rapper Ghostface Killah (Dennis Coles) votes Obama. Video still from "Obama Dirt off Your Shoulder Remix." YouTube video, uploaded 18 April 2008 by jarts (no longer available).

as he brushes off superimposed images of Hillary Clinton, Bill Clinton, Charles Gibson, George Stephanopoulos, and of course, the kitchen sink.

Another mashup based on the same speech, "Obama Dirt off Your Shoulder Remix," alternates footage of the candidate's gesture with his enviable "Crazy in Love" dance moves displayed on The Ellen DeGeneres Show (Figure 2a). After flashing a photo of Obama proudly standing in front of a towering Superman statue, "Dirt off Your Shoulder" fades out and Jay Z's "99 Problems" begins. As the phrase "I got ninety-nine problems but a bitch ain't one" blares out, the creator juxtaposes close-up, still images of a choleric-appearing Clinton with more footage of dancing Obama. The still images of Clinton's contorted, unnatural facial expressions make her appear a caricature of the stereotypical, militant feminist man-hater detractors wished to portray her as, whereas Obama becomes more human as the viewer watches his casual, fluid grooves captured in the video footage. These dance moves, like Bill Clinton's Elvis-inspired sax-blowing fifteen years earlier, affirm the candidate's coolness and pop culture cred. The mashup also establishes a comparison between the supporters of Obama and the supporters of Republican candidate John McCain: the cool, hip, and sexy support Obama (Figure 2b); portly, 


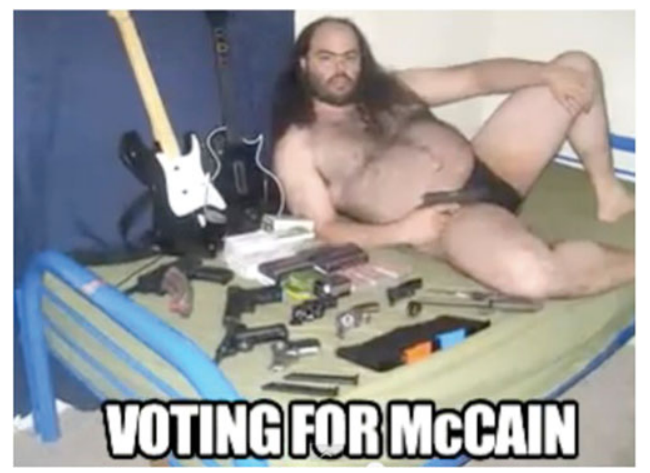

Figure 2c. Man with guitars and guns votes McCain. Video still from "Obama Dirt off Your Shoulder Remix." YouTube video, uploaded 18 April 2008 by jarts (no longer available).

gun-toting rednecks support McCain (Figure 2c). With these images, the creator unabashedly constructs racial and gender (and even class) stereotypes: black men have rhythm, feminists are angry, and poor whites cling to their guns. He also pairs images of "heroic" gangstas (including Obama) with images of objectified women and positions the viewer/voter as both a witness to the unfolding spectacle and a potential arbiter of taste: flat-chested women support Clinton, and voluptuous women endorse Obama (in this case, Natalie Portman and Scarlett Johansson, respectively). Using a hip hop-influenced filmic aesthetic, images are appropriated, recontextualized, and collaged to create a counter-narrative within campaign discourses-in this narrative, Obama becomes a "real" hip hop icon. He has the smooth moves, the superhuman status, the decorative women, and no one can stand in his way. ${ }^{40}$

According to the New York Times, viewers spent 14.5 million hours watching the Obama campaign's official content created for YouTube.$^{41}$ But the candidate's supporters (and detractors) were more than just passive spectators. On his campaign website, Obama offered voters sophisticated participatory frameworks that facilitated user invention and interactivity, and this spilled over into the musical realm. ${ }^{42}$ "Yes We Can" is the most well known music video of the 2008 campaign, but countless others created by the public circulated online. ${ }^{43}$ Music videos, newly composed songs, and mashups (like those created by users "jarts" and "Bill3948") drew from preexisting material, including candidate speeches, images, and songs.

${ }^{40}$ For more on how hip hop artists made Obama an "honorary member of the hip-hop community" and appropriated his image, see Gosa, "Not Another Remix," 398-403; and for more on "coolness" and Obama’s postsoul identity, see Ossei-Owusu, "Barack Obama's Anomalous Relationship," 219-23.

${ }^{41}$ Claire Cain Miller, "How Obama's Internet Campaign Changed Politics," Bits (blog), New York Times, 7 November 2008, http://bits.blogs.nytimes.com/2008/11/07/howobamas-internet-campaign-changed-politics/.

${ }^{42}$ Caroline E. Dadas, "Inventing the Election: Civic Participation and Presidential Candidates" Websites," Computers and Composition 25, no. 4 (2008): 416-31.

${ }^{43}$ Carol Vernallis, "Audiovisual Change: Viral Web Media and the Obama Campaign," Cinema Journal 50, no. 4 (Summer 2011): 73-97. 
One blogger even referred to 2008 as the "year of the campaign song." 44 The "Dirt off Your Shoulder" speech video responses I cite here are just a few of many instances where YouTube's participatory, video-based culture facilitated the construction of a dialogically constituted campaign soundscape.

\section{Obama: The "Old School” Guy}

Although the accessibility of social media and the availability of user-generated content sites have democratized the soundscape to some extent, candidates continue to control their sonic image by divulging their musical tastes and by selecting campaign playlists for their rallies and other appearances. Indeed, Obama needed to target the hip hop generation (a cohort with historically low participation in electoral politics), but his success in the primary was also to some extent contingent on his ability to draw in older black voters. Obama's rally playlists and personal playlists affirmed both his realness and respectability, as well as solidified his relationship with this constituency.

Establishing a narrative that positioned Obama's candidacy as an extension of the civil rights movement was a significant lineament of his overarching strategy. Obama was biracial, spent some of his formative years abroad, and was not a descendant of slaves; therefore, he did not share the same background or experience the same struggles as the black American political luminaries who paved the way for his success. In March 2007, shortly after announcing his candidacy, Obama merged his biography with the saga of the civil rights movement as he spoke at the Selma Voting Rights March Commemoration at Brown Chapel in Alabama, the departure point for the 1965 civil rights marches. In his speech, he discussed how the lives of his father (who was able to study in the United States because of Kennedy's policies) and his mother (who was permitted to marry his father), as well as his own aspirations for an education and political office, were made possible by the men and women who fought for civil rights in the 1960s. ${ }^{45}$ With the aplomb of a black preacher, he drew a parallel between the biblical heroics of Moses and the accomplishments of civil rights leaders (past and present), a rhetorical strategy adopted by Martin Luther King Jr. and other black church leaders who often imagined biblical heroes as their partners in struggle. Obama extended the lineage by positioning himself and his audience as "the Joshua Generation," citizens who possess the moral imperative to continue the battle "not just on behalf of African Americans but on behalf of all of America." 46 Although Obama began with the battles pertaining to civil rights, he positioned this historically specific struggle within larger struggles to ensure and preserve American freedoms. In

44 “The Campaign Song Comeback," From Fay To Z(blog), Fayetteville Observer, fayobserver.com, 29 October 2008.

${ }^{45}$ Several right-leaning websites questioned the accuracy of the biographical sketch Obama provided in this speech and criticized his fanciful rewriting of history. The Obama campaign later admitted that the candidate wrongly credited the Kennedy family for his father's scholarship, and that when referring to Selma, Obama was actually referring to the civil rights movement in general as opposed to the Selma March.

${ }^{46}$ Lynn Sweet, “Obama’s Selma Speech,” Sweet Blog (blog) Chicago Sun-Times, 5 March 2007, http://blogs.suntimes.com/sweet/2007/03/obamas_selma_speech_text_as_de.html. 
doing so, he bolstered his "political blackness" for aging black voters, the cohort defined by the civil rights movement, while still maintaining the relevance of the fight for (in a generalized sense) the public at large. ${ }^{47}$ Like Bill Clinton before him, Obama's "reaccentuation of rhetorical traditions in a performative display of practical wisdom" in his speeches allowed him to construct rhetorical authority, thereby affirming his legitimacy as a spokesperson for the black community. ${ }^{48}$

Personal and public playlists aided Obama in this quest for legitimacy. The presidential hopeful opined on his tastes in interviews for Rolling Stone, BET, MTV, Hot 97, and Vibe, as well as in a Blender article that polled both Obama and Republican opponent John McCain on their top-ten favorite songs. ${ }^{49}$ Although Richard Daniel Blim rightly describes the candidate's tastes as an eclectic mix with broad appeal, as Table 1 shows, black music of the 1960s and '70s dominated his list of preferences. ${ }^{50}$ The black performers Obama admires offer star personas and generic connotations that conjure up clusters of beneficial associations. For example, Miles Davis and John Coltrane, closely associated with innovations in jazz, reached the height of their success and recognition during the 1960s, the era when jazz accumulated significant cultural capital. But even setting aside the specifics of these canonized performers, the nostalgic music has something of value to offer the "old school" candidate. As Murray Forman has posited, the flexibility of the term "old school" allows it to be strategically deployed in generational contexts whereby it can project onto an individual values or virtues that connect them to something of enduring cultural value, rather than the ephemeral tastes of the present moment. ${ }^{51}$ Obama's enduring soundtrack musically aligns him with the values of the civil rights movement.

When creating rally playlists, the Obama team likely took their cues from the candidate's list of favorites-his "public" music is an extension of his private tastes.

\footnotetext{
${ }^{47}$ Ron Walters, "Barack Obama and the Politics of Blackness," Journal of Black Studies 38, no. 1 (September 2007): 7-29.

${ }^{48}$ John M. Murphy, "Inventing Authority: Bill Clinton, Martin Luther King, Jr., and the Orchestration of Rhetorical Traditions," Quarterly Journal of Speech 83, no. 1 (1997): 71-89.

${ }^{49}$ Wenner, "Conversation with Barack Obama;" "USA President Barack Obama Opinion on Hip-Hop \& Rap 2008” (BET); Calloway, "Barack Obama Gives a Shout-Out” (MTV); Barack Obama interview, Hot 97; Jeff Chang, "Barack Obama: The Vibe Interview," Vibe, September 2007, http://www.thelavinagency.com/content/speakers/58/1212688601_chang-vibe.pdf; Jon Coplon, "White House DJ Battle," Blender, 30 July 2008, https://web.archive.org/web/20080814151724/http:// www.blender.com/WhiteHouseDJBattle/articles/39518.aspx. This poll took place after Clinton conceded the Democratic nomination to Obama.

${ }^{50}$ Richard Daniel Blim, “The Electoral Collage: Mapping Barack Obama's Mediated Identities in the 2008 Election," chap. 5 in "Patchwork Nation: Collage, Music, and American Identity" (Ph.D. diss., University of Michigan, 2013), 404-8. For more on Obama's iPod, see Matthew F. Jordan, "Obama's iPod: Popular Music and the Perils of Postpolitical Populism," Popular Communication: The International Journal of Media and Culture 11, no. 2 (2013): 99-115. Several magazines, news outlets, and blogs, including Seventeen and NPR, discussed the contents of the candidates' lists. For an article that dissects Obama's 2008 rally music and offers an expert's analysis, see Margaret Talev, "Soul of the Obama Campaign Is in the Soundtrack," McClatchy D.C., 31 October 2008, http://www.mcclatchydc. com/2008/10/31/55103/soul-of-the-obama-campaign-is.html\#.UjHixDn3DfY. The expert is Mark Anthony Neal, a professor of African and African American studies at Duke University.

${ }^{51}$ Murray Forman, "Obama/Time: The President in the Hip Hop Nation," in The Hip Hop \& Obama Reader, ed. Travis L. Gosa and Erik Nielson (Oxford: Oxford University Press, 2015), 163.
} 
Table 1. Obama's Taste in Music, 2007-8. The table shows the music preferences Obama declared in interviews with Rolling Stone, BET, MTV, Hot 97, Vibe, and Blender. ${ }^{1}$

\begin{tabular}{|c|c|c|c|}
\hline $\begin{array}{l}\text { Artists/groups } \\
\text { cited in } \\
\text { interview(s) }\end{array}$ & $\begin{array}{l}\text { Artist/group } \\
\text { represented on } \\
\text { rally playlists }\end{array}$ & $\begin{array}{l}\text { Song or album } \\
\text { cited in } \\
\text { interview }(s)\end{array}$ & Genre \\
\hline Beyoncé & & & $R \& B$ \\
\hline John Coltrane & & & Jazz \\
\hline Common & & & Rap \\
\hline Sheryl Crow & $\mathrm{X}$ & & Pop/Rock \\
\hline Miles Davis & & & Jazz \\
\hline Bob Dylan & & $\begin{array}{l}\text { Blood on the Tracks } \\
\text { "Maggie's Farm" }\end{array}$ & Folk \\
\hline Earth, Wind \& Fire & $\mathrm{X}$ & & $R \& B$ \\
\hline Aretha Franklin & $\mathrm{X}$ & “Think" & $R \& B$ \\
\hline The Fugees & & "Ready or Not" & Pop/Rock, Rap \\
\hline Marvin Gaye & $\mathrm{X}$ & "What's Going On" & $R \& B$ \\
\hline The Grateful Dead & & & Pop/Rock \\
\hline Howlin' Wolf & & & Blues \\
\hline Isley Brothers & $\mathrm{X}$ & & $R \& B$ \\
\hline Jay Z & & American Gangster & Rap \\
\hline Elton John & & & Pop/Rock \\
\hline Yo-Yo Ma & & & Classical \\
\hline OutKast & & & Rap \\
\hline Charlie Parker & & & Jazz \\
\hline Nina Simone & & "Sinnerman" & Jazz \\
\hline Frank Sinatra & & "You'd Be So Easy to Love" & Pop \\
\hline Rolling Stones & & "Gimme Shelter" & Pop/Rock \\
\hline Bruce Springsteen & $\mathrm{X}$ & "I'm on Fire" & Pop/Rock \\
\hline The Temptations & $\mathrm{X}$ & & $\mathrm{R} \& \mathrm{~B}$ \\
\hline $\mathrm{U} 2$ & $\mathrm{X}$ & "City of Blinding Lights" & Pop/Rock \\
\hline Kanye West & $\mathrm{X}$ & "Touch the Sky" & Rap \\
\hline will.i.am & $\mathrm{X}$ & "Yes We Can"" & Rap, R\&B \\
\hline Stevie Wonder & $\mathrm{X}$ & $\begin{array}{l}\text { Music of My Mind } \\
\text { Talking Book } \\
\text { Innervisions } \\
\text { Fulfillingness' First Finale } \\
\text { Songs in the Key of Life }\end{array}$ & $\mathrm{R} \& \mathrm{~B}$ \\
\hline
\end{tabular}

\footnotetext{
${ }^{1}$ There are likely other crossovers between Obama's list of favorites (as recounted in the interviews cited above) and his rally playlists, but I have only indicated here the artists whose music I am fairly certain he used at his official rallies. Obama may have also cited additional artists as favorites in his other interviews. The music of Wonder, Crow, and West was also featured on Yes We Can: Voices of a Grassroots Movement, a compilation CD released by the campaign in order to raise funds for the general election. See Yes We Can: Voices of a Grassroots Movement, Hidden Beach, B001IF269Y, 2008, CD.
}

(The Xs in Table 1 indicate artists represented on Obama's rally playlists.) This continuity is significant, considering the fact that Hillary Clinton received a lot of flak for the list of songs her team preselected for her "Choose Our Campaign Song" contest ballot; critics questioned whether or not the ballot faithfully reflected her own musical interests. At rallies, Obama offered a diverse soundtrack overall-he used perennial candidate favorites U2, Bruce Springsteen, and Brooks \& Dunn, among others. The contents of the rally playlist shifted over the course of the campaign, and the candidate's team likely took into consideration the expected audience, the state of the campaign, and local preferences when making these decisions. However, as one playlist from a January 2008 event shows, R\&B formed 
1. "Ain't No Mountain High Enough" (1967) Marvin Gaye and Tammi Terrell

2. "St. Elmo's Fire (Man in Motion)" (1985) John Parr

3. "The Best" (1989) Tina Turner

4. "Takin' It To The Streets" (1976) The Doobie Brothers

5. "Shining Star" (1975) Earth, Wind \& Fire

6. "Give The People What They Want" (1975) The O'Jays

7. "Hold On, I'm Comin"” (1966) Sam \& Dave

8. "Celebration" (1980) Kool \& the Gang

9. "Unwritten" (2004) Natasha Bedingfield

10. "Shout" (1959) The Isley Brothers

11. "Get Ready" (1966) The Temptations

12. "There's Hope" (2006) India.Arie

13. "Ain't No Stoppin' Us Now" (1979) McFadden \& Whitehead

14. "I'll Take You There" (1972) The Staple Singers

15. "Still The One" (1976) Orleans

16. "Everyday People" (1968) Sly and the Family Stone

17. "Long Train Runnin"” (1973) The Doobie Brothers

18. "Sir Duke" (1976) Stevie Wonder

19. "Centerfield" (1985) John Fogerty

20. "City of Blinding Lights" (2004) U2 (for Obama entrance)

21. "Signed, Sealed, Delivered I'm Yours" (1970) Stevie Wonder

Figure 3. Playlist for a January 2008 Barack Obama rally. ${ }^{52}$

the backbone of his rally soundscape (Figure 3). Although not included on the list for this event, Curtis Mayfield's "Move on Up" (1970), Aretha Franklin's “Think" (1968), The Staple Singers' “I'll Take You There” (1972), and Jackie Wilson's “(Your Love Keeps Lifting Me) Higher and Higher" (1967) were in steady rotation as well. Of the twenty-one tracks on this rally playlist, ten can be classified as soul hits from the 1960s or 1970s. With the exception of the songs by Natasha Bedingfield, India.Arie, and U2, the entire list is comprised of songs that predate 2003. Like Bill Clinton before him, Obama fashioned his nostalgic campaign playlist with the sounds of his own coming of age.

Noting the affinities between Obama's message of hope and change and the ideals of Chicago Soul performers Sam Cooke, Curtis Mayfield, and The Staple Singers, one Chicago Sun-Times journalist even went so far as to claim that "the unbending spirit of the 1960s and '70s Chicago soul movement helped put Obama on that stage [in Grant Park for his victory speech]." ${ }^{53}$ Indeed the hip hop generation embraced Obama as their own, but so did fans of soul, who even started their own "Soul Music Lovers For Obama" group on his campaign website with the rallying call, "From the inner cities to the suburbs, Sen. Obama unites us like the music

\footnotetext{
${ }^{52}$ Dave Beard, “'Celebration' and 'There’s Hope' on Obama’s Setlist,” Boston.com, 5 January 2008, http://www.boston.com/news/politics/politicalintelligence/2008/01/celebration_and.html. Slate (and other websites) posted lists of the songs Obama used on the campaign trail. See Christopher Beam, "Barack Obama's iTunes Playlist," Trailhead (blog), Slate, 26 January 2008, http://www.slate.com/ blogs/trailhead/2008/01/26/barack_obama_s_itunes_playlist.html.

${ }^{53}$ Dave Hoekstra, "The Soul of a President," Chicago Sun-Times, 11 January 2009.
} 
we love." Although Millennials may have associated Obama's cool posture with the swagger of a rap icon, Mavis Staples saw an earlier model: Obama, she claims, "has that same walk Sam [Cooke] did with [the gospel group] the Soul Stirrers." 54 Others refused to accept the characterization of Obama as a hip hop icon: Chicago disc jockey Herb Kent, who twice featured a then-unknown Senator Obama on his radio segment "Battle of the Best," claimed, "He quotes soul music a lot. He's not a hip-hop person." 55

Rally playlists also aligned Obama with the ethos of Motown. With its slick, polished production style and pop-R\&B fusion, the genre appealed to a broad market while simultaneously bringing professional recognition to black artists as well as affording them artistic self-determination. Although one can argue that institutionalized racism and exploitation still persisted alongside practices that precipitated the integration and assimilation of black artists, retrospectively, Motown, its crossover music, and its artists have come to signify the breakdown of firmly entrenched social divisions as well as the promotion of interracial understanding ${ }^{56}$ - the central initiatives of the civil rights movement. In his live appearances for the candidate, Motown's erstwhile wunderkind, Stevie Wonder, directly referred to Martin Luther King Jr., the legacy of the civil rights movement, and Obama's place in that lineage. ${ }^{57}$ Ultimately, the music of Motown (and the other throwback tracks of the period that formed the core of the candidate's private and public soundtracks) sonically reinforced the lineage that both Obama and his supporters constructed in their speeches and through their alliances.

\section{Obama: The Romantic Lead}

While the candidate's cultural and political blackness, as articulated through his pop culture cred, elicited spirited debate over the course of the primary, so too did the women-loving-Obama phenomenon. The viral success of Obama Girl stands as perhaps the most visible and memorable artifact of this "craze," but the same soundtrack that appealed to Obama's civil rights forbears also fanned the flames of female fandom. That is to say, several of Obama's musical offerings positioned the candidate as more than just a "cool dad" and an "old school" brother. Music positioned Obama as a worthy object of the female gaze, a (presidential) romantic lead of sorts. ${ }^{58}$ An analysis of Stevie Wonder's "Signed, Sealed, Delivered I'm Yours"

${ }^{54}$ Quoted in Hoekstra, "Soul of a President."

${ }^{55}$ Quoted in Hoekstra, "Soul of a President."

${ }^{56}$ Suzanne E. Smith, Dancing in the Street: Motown and the Cultural Politics of Detroit (Cambridge, MA: Harvard University Press, 1999), 138.

${ }^{57}$ At a UCLA rally on 3 August 2008, Wonder punctuated his short speech by initiating an improvised call-and-response tune using the candidate's name. Not surprisingly, Wonder's performance inspired a remix that combined the "Obama scale" with auto-tuned Obama speeches. See "Stevie Wonder Sings Obama Song," uploaded 23 December 2008, video clip, YouTube, http://www.youtube. $\mathrm{com} /$ watch? $\mathrm{v}=\mathrm{ZN} 3 \mathrm{caKwHlK} 4 \&$ feature=related. For the remix, see "Doktor Love ft. Stevie WonderBarack Obama Song," uploaded 3 August 2008, video clip, YouTube, http://www.youtube.com/watch? $\mathrm{v}=$ guCcgfVUeZk.

${ }^{58}$ See Kyle-Anne Shiver, "Women Voters and the Obama Crush," American Thinker, 11 March 2008, http://www.americanthinker.com/2008/03/women_voters_and_the_obama_cru.html; and Judith Warner, "Sometimes a President Is Just a President," Opinionator (blog), New York 
(the song most closely associated with the Obama campaign) and the responses of female "fans" offer insight into how the soundtrack allowed the candidate to connect with his female constituents. Moreover, an investigation of the thematic content and musical connotations of the candidate's list at large shows how music mirrored his communication style, values, and vision, and likely shaped the public's perception of his presidential identity.

Wonder was a twenty-year-old prodigy when he released "Signed, Sealed, Delivered I'm Yours” on his critically successful album Signed, Sealed \& Delivered in $1970 .{ }^{59}$ Since then, he has received countless accolades for a career spanning six decades. The spirited song was a staple for 2008 rallies and the artist performed the song on the last night of the Democratic National Convention, before Obama's victory speech at Grant Park, and in sing-along style at the Neighborhood Inaugural Ball. An article in the New York Times revealed that Obama campaign chief strategist David Axelrod even used the song as an exclusive ringtone for incoming calls from the candidate. ${ }^{60}$ The song was also included on the campaign's compilation CD, Yes We Can: Voices of a Grassroots Movement. In his 2008 Rolling Stone interview, Obama, a lifelong Stevie fan, stated, "When I was just at that point where you start getting involved in music, Stevie had that run with Music of My Mind, Talking Book, Fulfillingness' First Finale, and Innervisions, and then Songs in the Key of Life. Those are as brilliant a set of five albums as we've ever seen." 61 The interview leaves no question in the mind of the reader as to whether or not Obama truly loves Wonder's music as he demonstrates here his keen knowledge of the artist's history and catalogue.

"Signed, Sealed, Delivered I'm Yours," narrated from a first-person perspective, features a man singing of his love for a woman who is "[his] heart's only desire." The song's verses, with musings such as "seen a lot of things in this old world / when I touched them they mean nothing, girl” and "That's why I know you're my heart's only desire," establish the relationship between the speaker and addressee as a monogamous one. Wonder and the backup singers punctuate these verses by singing the refrain "oo, baby, here I am, signed, sealed, delivered I'm yours" together in a homorhythmic texture with dense chordal harmonies. The homorhythmic verses give way to call-and-response textures with overlapping entries in the choruses and the coda. As the backup singers chant "signed, sealed, delivered" here, Wonder quips "you've got my future in your hands" above them, creating a layered effect, but with each line equally emphasized, perhaps suggesting equal footing between the male speaker and his female addressee. At the second bridge, one of the backup singers interrupts Wonder's line, "but here I am / with your future," with a wailing high note before he can sing the word "am," and thus, for a fleeting moment, a

Times, 5 February 2009, http://opinionator.blogs.nytimes.com/2009/02/05/sometimes-a-presidentis-just-a-president/.

${ }^{59}$ Stevie Wonder, Signed, Sealed \& Delivered, Tamla, TS304, 1970, LP. “Signed, Sealed, Delivered I'm Yours," words and music by Stevie Wonder, Syreeta Wright, Lee Garrett, and Lula Mae Hardaway. ${ }^{60}$ Jeff Zeleny, "Long By Obama's Side, An Adviser Fills a Role That Exceeds His Title," New York Times, 26 October 2008, http://www.nytimes.com/2008/10/27/us/politics/27axelrod.html?r=1.

${ }^{61}$ Wenner, "Conversation with Barack Obama." Innervisions (1973) actually predated Fulfillingness' First Finale (1974). 
woman takes up the vocal lead. The song's call-and-response texture asseverates their mutual celebration of shared affection.

At first glance, the hook, "signed, sealed, delivered I'm yours," may be understood as the declaration of a haughty and boastful lover who perceives himself as a "gift" to the addressee, or, in the case of the Obama campaign, the braggadocio of a hubristic politician who thinks he has clinched his party's nomination. However, an intertextual reading that considers all of the song's parameters against the backdrop of the candidate's platform and performance style may open an additional hermeneutic window. The playful interaction between Wonder and the backup singers, the surrounding text, and Wonder's own vocal stylings lessen the presumed arrogance of the hook, which simply states that the speaker (Wonder) "belongs" to the addressee (represented by the backup singers). The speaker's pronouncement, "I'm yours" (rather than you're mine), puts the addressee in the dominant position, not the speaker. The organization of voices, most significantly the fact that the female backup singers sing the hook along with Wonder in harmonious accord, suggests the addressee elatedly accepts his offer. The desire is mutual. In the rest of the song's verses, the speaker does not come across as arrogant in the slightest-he is actually the complete opposite, appearing meek and self-deprecating at times. He sings, "Like a fool I went and stayed too long" and "I've done a lot of foolish things," thus confessing his own wrongdoings. Although the song never makes clear what has transpired between this couple in the past, the phrase "now I'm back" could be an indication that some process of growth, self-awareness, or transformation has taken place in the man's life. Additionally, the speaker frames his happiness and restoration of wholeness as contingent upon her willingness to accept him. The addressee holds the power to accept or refuse what is signed, sealed and delivered to her. The speaker, in other words, can only be empowered through her, as she's got his future in her hands. The admission of culpability for some unstated transgression, the confession of brokenness, and an outward display of emotion (he is not afraid to cry) weakens, or one might argue, feminizes, the speaker. Text aside, Wonder's vocal style in the song, rooted in the tradition of female gospel singing with its exaggerated whoops, sighs, and stratospheric range, reinforces the man's subordinate position.

Before addressing how songs like "Signed, Sealed, Delivered I'm Yours" allowed Obama to engage with female voters, it might be fruitful to briefly explore the ways in which Wonder's song, and the rally playlists more broadly, mirrored and propagated discourses regarding Obama's own feminine style and its connection with his identity as a black candidate. In a 2008 editorial, Carol Marin stated, "If Bill Clinton was once considered America's first black president, Obama may one day be viewed as our first woman president." 62 Her journalistic piece is one of many that dissected the candidate's feminine communication style, rhetoric, and approach to leadership. According to scholars in the field of marketing research, Obama's values were "more collaborative, more human, more feelings-led and people-focused,"

\footnotetext{
${ }^{62}$ Carol Marin, "Thanks to Hillary for Being a Winner at Heart," Chicago Sun-Times, 11 May 2008.
} 
than Hillary Clinton's. ${ }^{63}$ Although the former First Lady's gender strategy morphed over the course of the primary, a supporter extolled her "testicular fortitude" late in the game, and Democratic Governor Mike Easley even claimed she "[made] Rocky Balboa look like a pansy." ${ }^{64}$ Indeed, Team Clinton played up their candidate's tenacity and framed her as a fighter, and in doing so, they mitigated the image of Hillary Clinton as First Lady and helpmeet to Bill Clinton, or even drew attention away from her failure to serve as a traditional helpmeet to him. ${ }^{65}$ Several articles in the mainstream press played up the apparent gender role reversal between the two Democratic frontrunners with titles such as "Leading Like a Girl: For Men Only," "Hillary is from Mars, Obama is from Venus," and "¿Quién Es Less Macho?”66

Whereas many candidates who preceded Obama primarily tapped into the concept of the "mythic presidency" by emphasizing the virtues of strength and charisma, the Obama campaign humanized the candidate by focusing on idealized intimate relationships. ${ }^{67}$ (The "concerned father" narrative that the candidate adopted in response to hip hop exemplifies this strategy.) The campaign soundtrack followed suit. Like other candidates before him, Obama did use the music of iconic rocker Bruce Springsteen, but rather than relying primarily on his testosterone-driven, rousing 1980s anthems, he featured songs like "The Rising" from the artist's post-9/11 album of the same title, which meditates on the themes of redemption and healing. ${ }^{68}$ The Boss himself offered live performances of some of his older, melancholy and introspective songs, such as "The Promised Land," "Youngstown," and "Thunder Road," at a few Obama rallies. Although far less subdued, the songs recorded by Stevie Wonder, Jackie Wilson, and Curtis Mayfield are smooth and sentimental, and the general tenor is the power of love as opposed to power chords. ${ }^{69}$ It would be somewhat of an overgeneralization to describe this music as "feminine" per se;

${ }^{63}$ Philippa Roberts and Jane Cunningham, "Feminisation of Brands," Marketing, 2 September 2008; see also Katherine Adam and Charles Derber, The New Feminized Majority: How Democrats Can Change America with Women's Values (Boulder, CO: Paradigm, 2008).

${ }^{64}$ Quoted in Mike Memoli, "Hillary's 'Testicular Fortitude,"” NBC News, 30 April 2008, http:// firstread.nbcnews.com/_news/2008/04/30/4437744-hillarys-testicular-fortitude.

${ }^{65}$ Douglas Kellner, "Barack Obama and Celebrity Spectacle," International Journal of Communication 3 (2009): 719-20, https://pages.gseis.ucla.edu/faculty/kellner/essays/2009_ ObamaCelebritySpectacle.pdf.

${ }^{66}$ Maureen Dowd, “¿Quién Es Less Macho?" New York Times, 24 February 2008, http://www.nytimes.com/2008/02/24/opinion/24dowd.html? $r=3 \& s c p=36 \& s q=$ maureen+dowd\&st= nyt\&oref=slogin\&oref=slogin; Marie Wilson, "Leading Like a Girl: For Men Only?" Huffington Post, 15 April 2008, http://www.huffingtonpost.com/marie-wilson/leading-like-a-girl-for-m_b_96753. html; Michael Scherer, "Hillary is from Mars, Obama is from Venus," Salon, 12 July 2007, http:// www.salon.com/news/feature/2007/07/12/obama_hillary/.

${ }^{67}$ For more on the concept of the mythic presidency, see Patricia S. Misciagno, "Rethinking the Mythic Presidency," Political Communication 13, no. 3 (1996): 329-44.

${ }^{68}$ Brian Garman, "Models of Charity and Spirit: Bruce Springsteen, 9/11, and the War on Terror," in Music in the Post-9/11 World, ed. Jonathan Ritter and J. Martin Daughtry (New York: Routledge, 2007): 71-89.

${ }^{69}$ For more on sentimentality and black music, see chapters 2 and 3 in Mitchell Morris, The Persistence of Sentiment: Display and Feeling in Popular Music of the 1970s (Berkeley: University of California Press, 2013). 
however, these songs shun the more virulent, aggressive aspects of masculinity in favor of an ethos of nurturing, caring, and responsiveness. ${ }^{70}$

Pre-2008 campaign playlists of preexisting music favored solo male performers or all-male bands; however, the Obama camp embraced music by female performers, and in some instances, featured songs with female voices as backup-perhaps suggesting a harmony between the genders, rather than "one man triumphs over adversity" narratives. In one coffee shop appearance (where the candidate brought along his younger daughter Sasha), the Indigo Girls' female empowerment anthem "Hammer and a Nail" preceded his speech. ${ }^{71}$ Although the Indigo Girls never became standard fare at Obama events, the music of another feminist artist did. Like "Signed, Sealed, Delivered I'm Yours," Aretha Franklin's “Think" offers a spirited refrain. In this song, the singer and her backup vocalists (or the audience) bandy the word "freedom" back and forth (which at least partly explains its appeal as a campaign song). Considering the performer's iconic status and the song's strong connection with both the civil rights and women's equality movements, its connotations related to racial equality, black self-determination, and female empowerment may be more significant than the speaker's actions as explored in the lyrics, which, like Wonder's, elevate heterosexual monogamy. The song's funky style, blaring horn section, and kinetic drive that incrementally increases in both texture and dynamic level, as well as Franklin's raw vocal style, epitomize the "say it out loud, I'm black and I'm proud" ethos of soul artists in the 1960s and 1970s who refused to bend to more polished, pop-oriented methods of production.

As a black candidate, Obama could not uncritically embrace the garden-variety "regular guy" tropes deployed by the white male candidates who preceded him, Jackson Katz argues. ${ }^{72}$ We see such tropes in the playlist of Obama's Republican opponent, John McCain, who made use of "Gonna Fly Now" and "Eye of the Tiger" (from the Rocky films), songs that surely reinforce what Katherine Adam and Charles Derber call the "supermasculinized vision of international politics" that defined the Republican brand in $2008 .{ }^{73}$ In selecting nostalgic and sentimental love songs such as Wonder's, and also Wilson's “(Your Love Keeps Lifting Me) Higher and Higher," Obama performs the comforting and assimilationist "Good Black Man" side of what Frank Rudy Cooper calls bipolar black masculinity. A desire to avoid perpetuating stereotypes about black male sexuality, that is, Cooper's threatening and race affirming "Bad Black Man" side of black bipolarity, may have steered the candidate's team away from selecting other artists of the same era such as James Brown or Wilson Pickett. ${ }^{74}$ This stereotype is of course another reason why Obama kept hip hop at a safe distance while skillfully appropriating some of its linguistic

${ }^{70}$ Mayfield's "Move on Up" does not deal with romantic attachment, but the opening invocation "Hush now child and don't you cry," is reminiscent of a lullaby, a genre historically identified with the maternal feminine.

${ }^{71}$ Scherer, "Hillary is from Mars, Obama is from Venus."

72 Jackson Katz, Leading Men: Presidential Campaigns and the Politics of Manhood (Northampton, MA: Interlink, 2013), 4.

${ }^{73}$ Adam and Derber, New Feminized Majority, 139.

${ }^{74}$ Frank Rudy Cooper, "Our First Unisex President?: Black Masculinity and Obama's Feminine Side,” Denver University Law Review 86, no. 3 (2009): 633. 
and gestural modes of signification. ${ }^{75}$ In her study on visual representation and presidential masculinities, Emma Cannen argues that "whilst Obama transcends mainstream hip hop's construction and promotion of African American men as hypersexual violent criminals, he retains and embodies its maleness, ghetto-cool and aura of protest masculinity."76 An "aura of protest" still shaped the rally playlists, but the candidate chose the safer route of specifically female protest with songs by Franklin and the Indigo Girls (not surprisingly, Franklin's "Respect" also made the Obama soundtrack, albeit with less frequency).

Whereas Hillary Clinton attempted to downplay her marriage, Obama highlighted his role in the familial sphere and frequently praised his wife. Indeed, songs such as Wonder's, which praise monogamy, and Wilson's, which apotheosizes the saving power of romantic attachment, elevate the domesticated male as a source of inspiration. As I cited earlier in my discussion of Obama's response to hip hop lyrics, the candidate often alluded to the fact that he was the father of two young daughters when calling for social change and spoke in relational terms about the importance of nurturing parents. In one instance he went so far as to criticize absentee black fathers for failing their children. ${ }^{77}$ Indeed, the candidate aligned himself with what Anthony Lemelle calls "dutiful masculinity," in that he emphasized the centrality of family and fatherhood in the life of the black male. ${ }^{78}$

But Obama's soundtrack did not only reinforce his image as a sensitive guy and devoted husband, it also served him up as a romantic leading man. Images circulating during election season playfully engaged with the female fascination with Obama, often relying on the establishment of a parallel between romantic attachment and devotion to progressive politics: The image in Figure 4a finds its inspiration in an anti-Vietnam War poster that featured Joan Baez and her sisters making a similar pledge to boys who resisted the draft. Taking the pacifist statement "GIRLS SAY YES to boys who say NO" as a point of departure, the photographer posits a more current and witty mapping of the personal onto the political— "GIRLS SAY YES to boys who say OBAMA." "79 In the popular YouTube video "I Got a Crush on Obama," model Amber Lee Ettinger (Obama Girl) boldly positions the candidate as an object of both political and sexual desire (Figure $4 \mathrm{~b}$ ). ${ }^{80}$ The candidate himself did not respond too fondly to a scantily clad Ettinger's performance: In an interview, he acknowledged the lighthearted tone of the video, but said he "wish[ed] people

\footnotetext{
${ }^{75}$ For more on Obama's appropriation of hip hop culture in his speeches, see Alim and Smitherman, "My President's Black.” See also Sanford K. Richmond, "Paint The White House Black!! A Critical Discourse Analysis Look at Hip Hop's Social, Cultural, and Political Influence on the Presidency of Barack Obama," Western Journal of Black Studies 37, no. 4 (Winter 2013): 249-57.

${ }^{76}$ Emma Cannen, "Avant-Garde Militarism and a Post-Hip-Hop President," International Feminist Journal of Politics 16, no. 2 (2014): 268.

77 “Text of Obama's Fatherhood Speech," Politico, 15 June 2008, http://www.politico.com/news/ stories/0608/11094.html.

${ }^{78}$ Anthony J. Lemelle, Black Masculinity and Sexual Politics (New York: Routledge, 2010), xiv.

${ }^{79}$ The women who created this Obama poster are Andrea Swensson, Alexa Jones, and Stacy Schwartz (L to R). A group of women from Brooklyn created the first Obama-themed remake. To see the Brooklyn version next to Joan Baez's original, see Judy Berman, "Putting Out for Barack," Salon, 23 October, 2008, http://www.salon.com/2008/10/23/girls_say_yes/.

80 "Crush on Obama," 13 June 2007, video clip, YouTube, http://www.youtube.com/watch? $\mathrm{v}=\mathrm{wKsoXHYICqU}$.
} 


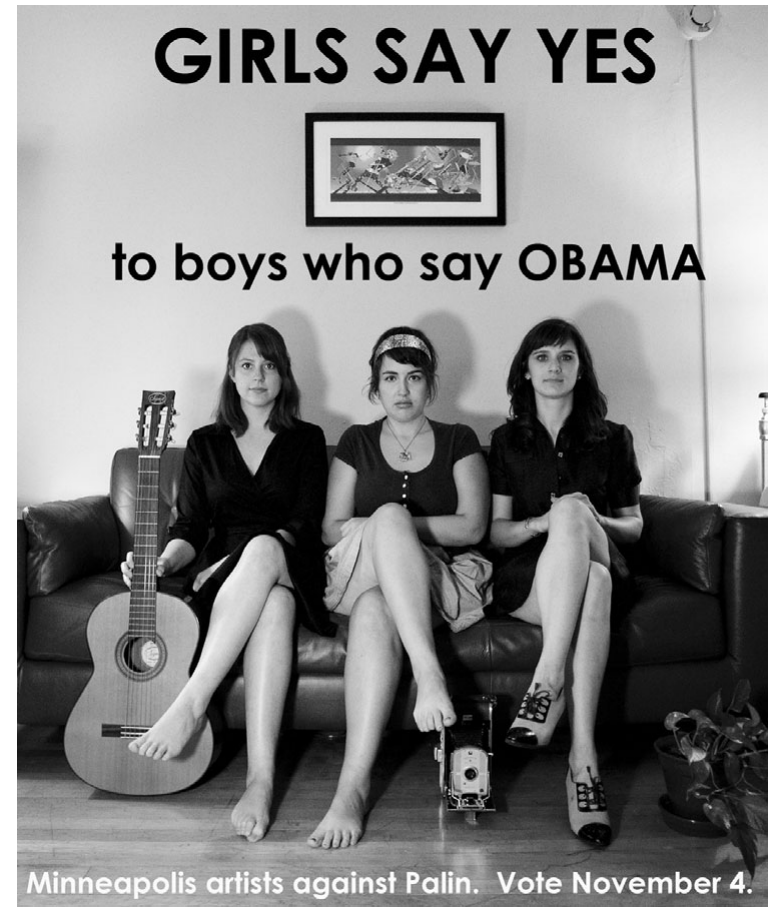

Figure 4a. "Girls say yes to boys who say Obama." Campaign poster. Reprinted by permission of Andrea Swensson, Alexa Jones, and Stacy Schwartz (L to R).

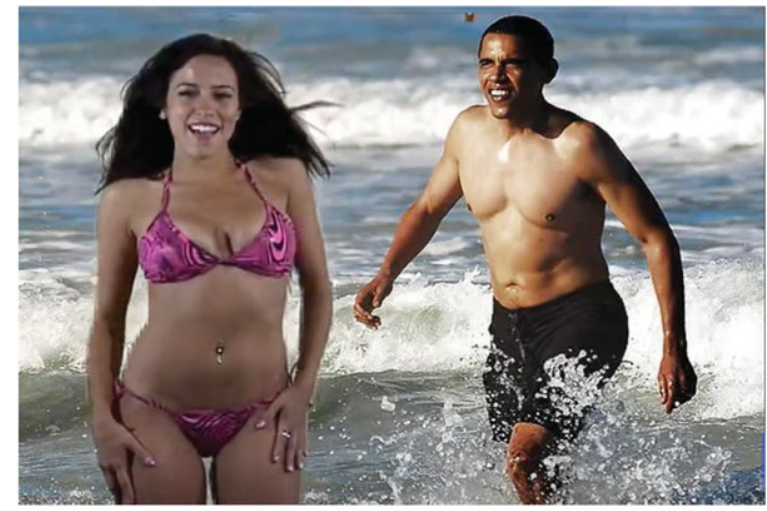

Figure 4b. Amber Lee Ettinger as "Obama Girl" in "I got a crush on Obama." Video still from "Crush on Obama." Vocals: Leah Kauffman; lyrics: Leah Kauffman and Ben Relles; music: Leah Kauffman and Rick Friedrich. YouTube video uploaded 13 June 2007 by Barely Productions, http://www.youtube.com/watch? $\mathrm{v}=$ WKsoXHYICqU.

would think about what impact their actions have on kids and families" - yet another performance of dutiful masculinity in response to questionable music. The general public's response, however, was quite different: the video received 3.1 
million "hits" on YouTube between June and August of $2007 .{ }^{81}$ But of course not everyone embraced "Obama Mania” with unbridled enthusiasm:

Everywhere Obama goes, before he even opens his mouth, Democrat women fall all over themselves in awe. They chant. They swoon. They get so all fired up and excited that they don't even seem to consider what utter fools they are making of themselves. ... I've actually heard women say they love him, though they know nothing about him except that he is running for president. $^{82}$

This conservative commentator, who berated citizens affected by the "Obama Crush," claimed the phenomenon only served to prove the mindless ignorance of liberal women.

Like "I Got a Crush on Obama," several of the preexisting songs featured at rallies_- “Signed, Sealed, Delivered I'm Yours," “Think,” “(Your Love Keeps Lifting Me) Higher and Higher," and "Ain't No Mountain High Enough"-explore the dimensions of romantic relationships. Although the women seem to have the upper hand in the unions represented, and the men show hints of vulnerability, both music and lyrics affirm that it takes two, and thus, with these songs, the candidate reaffirms the traditional values of family and fidelity, but with a progressive edge. The Obamas themselves exemplify this relationship dynamic: Barack once stated, "It's true my wife is smarter (and better looking)—she's also a little meaner than I am." 83 And as an article titled "Wife Lessons: Why Michelle Obama is No Hillary Clinton" pointed out, the press embraced Michelle's "Tough Broad" narrative, describing her as "strong-willed," "gutsy," "regal," "steely," "direct," "outspoken," and "military" in bearing. ${ }^{84}$ Her stereotypically masculine traits may have feminized the candidate to a certain extent, but like Obama's own deployment of a feminized communication style, such gendered performances on her part allowed him to transcend stereotypes regarding black masculinity without appearing emasculated.

Within the context of women-loving-Obama discourses, the lover (speaker)beloved (addressee) relationship in the songs can symbolize the desired, ideal candidate-voter relationship, and a desire for monogamy can become analogous with political loyalty. Figure 5 illustrates how the personal might be mapped onto the political in "Signed, Sealed, Delivered I'm Yours." Like the addressee in Wonder's song, who is in a position to empower the speaker through her love, the women constituents are in a position to empower the candidate-which they accomplish through voting (the ultimate civic responsibility). Man (the candidate) is made (president) through Woman (the female voter). Thus, this symbolic exchange establishes a system of reciprocity: women empower the candidate with votes and in turn the candidate empowers women through his progressive social policies.

${ }^{81}$ Michael Falcone, “Obama on 'Obama Girl,"” The Caucus (blog), New York Times, 20 August 2007, http://thecaucus.blogs.nytimes.com/2007/08/20/obama-on-obama-girl/.

${ }^{82}$ Shiver, "Women Voters and the Obama Crush." Emphasis in original.

${ }^{83}$ Quoted in Nick Miller, "The Good Wife," Sydney Morning Herald, 27 May 2012, http://www. smh.com.au/world/the-good-wife-20120526-1zbs5.html.

${ }^{84}$ Michelle Cottle, "Wife Lessons: Why Michelle Obama Is No Hillary Clinton," New Republic 238, no. 5, 26 March 2008, 23. 
Speaker [Man] (empowered by) $\rightarrow$ Addressee [Woman] can achieve wholeness

OR

If voters use romantic terms to articulate a "political" relationship:

Presidential Candidate [Man] (empowered by) $\rightarrow$ Voter [Woman] can become president

AND

Voter [Woman] (empowered by) $\rightarrow$ President [Man] can gain agency through his progressive social policies

Figure 5. "Signed, Sealed, and Delivered": Obama and the Woman Voter; the Personal Becomes Political. Figure by author.

In discussing the content of pop songs and their potential to evoke emotional responses, Simon Frith argues, “[p]op love songs do not 'reflect' emotions, then, but give people the romantic terms in which to articulate and so experience their emotions." 85 A questionnaire and interviews I conducted with women who attended 2008 Obama rallies suggest songs that employ what Frith calls "romantic terms" can indeed be used by voters to articulate their relationships to a politician. Consider one fifty-year-old woman's response to the question, what does the phrase "signed, sealed, delivered I'm yours" mean to you?

As a love song (originally) of course it means I give myself to the other totally, completely. In the context of the election, I feel it is meant to convey loyalty, truth and hope. Upon reflection, I believe it to mean that the action is reciprocal. In taking the gift of my complete commitment to the other, I am also offering trust, which I hope to receive in return. Signed and sealed - a relationship that I would hope to be getting back in the same spirit in which I, my "self," is offered. ${ }^{86}$

The informants were not specifically asked to comment on how their understanding of the song's romantic relationship might be understood as political allegiance or affiliation. However, several responded to the question by drawing an analogy between the two. In her response, this informant zones in on loyalty, truth, and reciprocity-three themes touched upon in the song. She also suggests that the song implies "hope," even though the lyrics do not make a direct or even oblique reference to this sentiment. She may be recalling a prevalent theme in Wonder's song catalogue, or perhaps the idea of hope came to her mind because it served as a central tenet of Obama's campaign platform. As Peter Wicke has posited:

The "content" of rock songs cannot be reduced to what is directly played or even what appears to be expressed in the lyrics. For its listeners these aspects only form the medium of which they themselves make active use. They integrate them into their lives and use them as symbols to make public their own experiences, just as, seen from another angle, these

${ }^{85}$ Simon Frith, Sound Effects: Youth, Leisure, and the Politics of Rock 'n' Roll (New York: Pantheon, 1981), 123.

${ }^{86}$ This informant attended the Harrisonburg, Virginia rally at James Madison University on 28 October 2008. 
aspects give the experience of social reality a cultural form conveyed by the senses and thereby influence that reality. ${ }^{87}$

In other words, just as the informant projects the foundation for a strong romantic relationship onto a possible political one with Obama, Obama's campaign message inflects her reading of the song. The participatory engagement motivated by the song's prominent texture-call and response-works to facilitate this exchange on a sonic level. Richard Middleton claims call and response signifies conversation and mutuality, and I would argue that this texture, which pervades Obama's soulcentric playlists, establishes a spirited dialectic between the songs' lead vocalists and backup singers, who may stand in for Obama and his female voters respectively. ${ }^{88}$

Of course, not all female voters engaged with the music in this way. One twentytwo-year-old rally attendee provided the following response to the "Signed, Sealed, Delivered I'm Yours" inquiry: "[The song has] got a good beat, and [it is] fun to listen to, but I don't really think about anything while listening." 89 Even if the attendees do not engage with the song's lyrics and themes in the manner shown in Figure 5, the act of participating in and of itself reinforces the idea of mutuality for attendees at any level of musical competence. The young informant affirms this viewpoint: observing the rally attendees' responses to the song, she reports, "Most people clapped or sang along. It was a very charged atmosphere.” Music, in this sense, engenders entrainment, what Satinder P. Gill refers to as "the coordinating of the timing of our behaviors and the synchronizing of our attentional resources." 90 In the videos I viewed of Obama rallies, supporters chose to sing either the call or the response portions of songs; such involvement requires them to listen, wait, and respond at the right moment. Although they might not view their participatory gestures as an affirmation of loyalty to the candidate, the physical act of singing and the active engagement requisite to call and response are powerful exercises in community building that allow voters to see and hear the harmonious communities Obama imagines in his speeches.

As Frith suggests, music (in this case, campaign music) can serve as the vehicle through which people voice their emotions. Perhaps the presence of music allows feeling to trump fact. As Katz suggests in his study of presidential masculinity, "presidential elections in the age of media spectacle are won and lost largely in the realm of myth, symbolism, and identity, where feelings about a candidate's intangible qualities of character, stature, and gravitas carry much greater weight than facts about where they stand on issues or whose economic interests they actually represent." 91 The role music played in the Obama campaign's success

\footnotetext{
${ }^{87}$ Peter Wicke, Rock Music: Culture, Aesthetics, and Sociology, trans. Rachel Fogg (Cambridge: Cambridge University Press, 1990), ix. Emphasis in original.

${ }^{88}$ Middleton, "From Me to You," 232.

${ }^{89}$ Question: "Because he used 'Signed, Sealed, Delivered I'm Yours' for his campaign, we now often associate this song with Barack Obama, but the song has been around a long time. What else does this song make you think about?" This informant attended the Harrisonburg, Virginia rally at James Madison University on 28 October 2008.

${ }^{90}$ Satinder P. Gill, "Entrainment and Musicality in the Human System Interface," Artificial Intelligence and Society 21, no. 4 (June 2007): 568.

${ }^{91} \mathrm{Katz}$, Leading Men, 3. Italics in the original.
} 
cannot be definitively determined, but clearly the candidate did appeal to female voters: women represented 42.2 percent of his campaign donors, whereas only 28 percent of John McCain's came from this group. ${ }^{92}$ As Caroline Streeter suggests, the Obama crush was not the exclusive purview of female voters - the media had its own "crush on Obama." "Saturday Night Live even featured a skit on the Obama crush with impersonators for news reporter Campbell Brown (a self-proclaimed Obamanic), and journalists John King (who recently suffered his third Barack-attack) and Jorge Ramos (an Obama stalker) mooning over Obama while shamelessly sidelining his opponent, Hillary Clinton. ${ }^{94}$

\section{Obama: A Real Respectable Candidate}

Responding to the media hype that surrounded his U.S. senatorial bid and 2004 Democratic National Convention keynote speech invitation, Obama claimed that he was "rooted in the African American community but not limited to it." 95 Indeed, Obama's multiracial, multiethnic background presented his campaign team with formidable challenges. However, as the cultural and musical analyses in this essay reveal, the candidate generated a campaign soundscape and established music alliances that allowed him to successfully navigate these challenges and ultimately forge a presidential brand that appealed to the politically disenfranchised hip hop generation as well as to older constituencies of black voters and female voters. To use Keli Goff's terms, Obama's music strategy allowed him to speak for hip hop voters and Huxtable voters. ${ }^{96}$

As Gosa has argued, "the racialization of Obama as the black (male), hip hop president was at odds with the image of Obama as the post-racial candidate for all Americans." 97 The candidate's deft musical balancing act mitigated this quandary. Although the circulation of Obama's voice and image in user-generated, hip hop styled videos imbued the candidate with street cred and hypermasculine bravado, he deployed various distancing strategies to safeguard his respectable image. The "cool dad" offered effusive praise for hip hop's genius and creativity while criticizing the conditions that gave rise to its poetic content, and by doing so, he tacitly informed impoverished black communities that he comprehended the complexity of their social situation, while simultaneously affirming his adherence to mainstream values.

Obama did not always keep it real, but neither did hip hop. To a certain extent, the tension between authentic artistic expression and commercial endeavor/corporate

92 The Center for Responsive Politics website tracks federal campaign contributions and lobbying activity. See "Donor Demographics By Gender," 13 July 2009, http://www.opensecrets.org/pres08/ donordemCID_compare.php?cycle=2008.

${ }^{93}$ Caroline A. Streeter, "Obama Jungle Fever: Interracial Desire on the Campaign Trail," in The Iconic Obama, 2007-2009: Essays on Media Representations of the Candidate and New President, ed. Nicholas A. Yanes and Derrais Carter (Jefferson, NC: McFarland, 2012), 167-83, esp. 171-72.

${ }^{94}$ SNL skit, Saturday Night Live, Season 33, episode 5, 2008. See also Bernard Goldberg, $A$ Slobbering Love Affair: The True (and Pathetic) Story of the Torrid Romance between Barack Obama and the Mainstream Media (Washington, D.C.: Regnery, 2009).

${ }^{95}$ Mark Leibovich, "The Other Man of the Hour," Washington Post, 27 July 2004, http://www. washingtonpost.com/wp-dyn/articles/A16606-2004Jul26.html.

${ }^{96}$ Goff, Party Crashing, 34.

${ }^{97}$ Gosa, "Not Another Remix," 398. 
interests has defined hip hop from its inception. And, one can argue, that limits its political economy, at least in the context of electoral politics. Conversely, one might argue that hip hop's internal struggles are what allow it to represent, or speak for, Obama in profoundly meaningful ways. ${ }^{98}$ Obama's complex biography and hip hop's interior conflicts, as well as its position within a larger constellation of music genres, mirror the broader political and social struggles that have defined racial politics in the post-civil rights era. It is also worth noting that the hip hop artists Obama heralds as agents of change frequently sample from the hits of their black music progenitors: Wonder, Mayfield, and Gaye. Through their musical appropriation, they share in the same legacy as Obama, who appropriates the political tropes and rhetorical strategies of his black political forebears to carve out his own legitimacy and respectability.

Just as Obama used biography to forge an alliance between himself and Selma, and thus the legacy of early civil rights activists, his nostalgic soul playlists culturally aligned him with the soundtrack of this historic struggle. Although these selections offer a universal theme-love-the sonic qualities of the songs that tell the stories not only signify blackness, but also more specifically, embody a style of black music associated with racial uplift, mainstream tastes, and middle-class respectability. The pairs of lovers who unite in the songs can be understood as symbolic representations of Obama and the female voter, but the duos can also act as placeholders for any two entities coming together-men and women (as suggested by the songs' lyrics); black and white communities (as implied by the songs' historical position and in the case of the Motown songs, the label's assimilationist stance); or larger, socially diverse communities divided by race, class, religion, geographic boundaries, or political affiliation (as implied when the songs are read against Obama's universalizing campaign rhetoric). Although the struggles these songs explore are framed as romantic ones, the prevailing narrative of overcoming adversity, which underlies the biographies of artists like Wilson and Wonder, speaks to the black experience of the 1960s, as well as to the contemporary, national struggles the candidate framed as "battles" to be fought by the Joshua generation. That is to say, music encouraged black voters to envision Obama as a partner in their struggles in both the past and the present. Responding to Obama's inspirational soundtrack at a rally in Pittsburgh, one voter articulated this connection: "We can't wait till it's signed, sealed, and delivered. We like Stevie Wonder because he's an inspiration, just like this man [Obama]. Nothing kept them down." 99 Ultimately, the rally playlists not only contributed to the identity formation of the candidate, but also reinscribed a set of values for his constituency — community, human rights, and equality, as well as family, fidelity, and civic-mindedness.

\footnotetext{
${ }^{98}$ For further discussion on how Obama constructed his American identity, see Etse Sikanku and Nicholas A. Yanes, "The Modern E Pluribus Unum Man: How Obama Constructed His American Identity from His Global Background," in The Iconic Obama, 2007-2009: Essays on Media Representations of the Candidate and New President, ed. Nicholas A. Yanes and Derrais Carter (Jefferson, NC: McFarland, 2012), 16-27.

99 Talev, "Soul of the Obama Campaign."
} 
In the United States, black masculinity, Anthony Lemelle argues, is "marked by its social feminization and simultaneously by its stereotyped hypermasculinization." 100 Obama's music strategy allowed him to simultaneously occupy both poles, as well as many positions in between them. Although some hip hop artists and audiences constructed Obama as the stereotypical black male, the candidate proclaimed fandom for music more closely aligned with his feminine communication style. As an "old school" candidate, Obama-who, according to Michael Scherer, is from Venus-more closely identified with the sentimental protagonists in the songs of Wonder and Wilson. To women swept up by Obama Mania, the senator from Illinois was part presidential candidate, part celebrity, part romantic lead, and music allowed their playful objectification to work to the candidate's advantage.

In the 2008 Obama campaign, "Hope" was not only a speech, slogan, and sound bite, but also a soundtrack that catapulted Obama to the status of superbrand. With the boundary between the political and pop cultural fields effaced, a presidential candidate's cultural competence can function as a form of political competence, and his music-aesthetic disposition can offer insight into his political values. Ultimately, a creative music strategy and the discourses it precipitated allowed Barack Obama to embody a safe middle ground between the race-specific and the universal, the masculine and the feminine, the past and the present, and most importantly, the real and the respectable. ${ }^{101}$

\section{References}

\section{Books and Articles}

Adam, Katherine, and Charles Derber. The New Feminized Majority: How Democrats Can Change America with Women's Values. Boulder, CO: Paradigm, 2008.

Alim, H. Samy, and Geneva Smitherman. Articulate While Black: Barack Obama, Language, and Race in the U.S. Oxford: Oxford University Press, 2012.

Beam, Christopher. "Barack Obama's iTunes Playlist.” Trailhead (blog). Slate, 26 January 2008. http://www.slate.com/blogs/trailhead/2008/01/26/barack_obama_ s_itunes_playlist.html.

${ }^{100}$ Lemelle, Black Masculinity and Sexual Politics, 2.

${ }^{101}$ For more on Obama in 2012, see the special issue of Music \& Politics James Deaville and I edited. My article, “I've Got a Little List': Spotifying Mitt Romney and Barack Obama in the 2012 U.S. Presidential Election," investigates the function of the candidate and voter-generated playlists that circulated during campaign season. In addition to providing a history of music's functions in campaign pageantry, Deaville's article, "The Sound of Media Spectacle: Music at the Party Conventions," addresses the role of music in establishing Party identity. Drawing on Douglas Kellner's work on spectacle and Thomas Frank's work on hipness, Joanna Love's, article, "Branding a Cool Celebrity President: Popular Music, Political Advertising, and the 2012 Election," analyzes the pop music signifiers in two Obama Internet advertisements and investigates their role in establishing the candidate's brand. Last, Michael Saffle's article, "User-Generated Campaign Music and the 2012 U.S. Presidential Election," investigates the phenomenon of newly composed music on YouTube. Music \& Politics 9, no. 2 (2015), http://quod.lib.umich.edu/m/mp/. Also see Jeffries, "Where ya at?" 314-26; and Erik Nielson, "How Hip-Hop Fell Out of Love with Obama," Guardian, 23 August 2012, http:// www.theguardian.com/music/2012/aug/23/why-hip-hop-deserting-obama. 
Beard, Dave. “'Celebration' and 'There's Hope' on Obama’s Setlist.” Boston.com, 5 January 2008. http://www.boston.com/news/politics/politicalintelligence/2008/ 01/celebration_and.html.

Berman, Judy. “Putting Out for Barack.” Salon, 23 October 2008, http://www.salon. com/2008/10/23/girls_say_yes/.

Blim, Richard Daniel. “The Electoral Collage: Mapping Barack Obama’s Mediated Identities in the 2008 Election." Chap. 5 in "Patchwork Nation: Collage, Music, and American Identity." Ph.D. diss., University of Michigan, 2013.

Bosman, Julie. "The Inner Obama." The Caucus (blog). New York Times, 24 June 2008. http://thecaucus.blogs.nytimes.com/2008/06/24/the-inner-obama/?' php $=$ true $\&$ type $=$ blogs $\&$ gwh $=3$ EF7CD36484138BE20A4B2BFD948B389\& gwt $=$ pay\&:r $=0$.

“Bush's iPod Reveals Music Tastes.” BBC News, 13 April 2005. http://news.bbc.co. uk/2/hi/4435639.stm.

Calloway, Sway. "Barack Obama Gives a Shout-Out to Hip-Hop." MTV, 27 September 2008. http://www.mtv.com/news/1595820/barack-obama-givesa-shout-out-to-hip-hop/.

Cannen, Emma. "Avant-Garde Militarism and a Post-Hip-Hop President.” International Feminist Journal of Politics 16, no. 2 (2014): 255-77.

Center for Responsive Politics. "Donor Demographics By Gender.” 13 July 2009. http://www.opensecrets.org/pres08/donordemCID_compare.php? cycle=2008.

Chang, Jeff. "Barack Obama: The Vibe Interview." Vibe, September 2007. http:// www.thelavinagency.com/content/speakers/58/1212688601_chang-vibe.pdf.

Chiachiere, Ryan. "Imus Called Women's Basketball Team 'Nappy-Headed Hos." Media Matters, 4 April 2007. http://mediamatters.org/research/2007/04/04/ imus-called-womens-basketball-team-nappy-headed/138497.

Clinton, Bill. "Remarks of Governor Bill Clinton." Rainbow Coalition National Convention. Washington, D.C., 13 June 1992. http://www.ibiblio.org/pub/ academic/political-science/speeches/clinton.dir/c23.txt.

Coleman, William. "Music in the American Democratic Process: The 1840 and 2008 Presidential Elections." Australasian Journal of American Studies 29, no. 2 (December 2010): 1-23.

Cooper, Frank Rudy. “Our First Unisex President?: Black Masculinity and Obama’s Feminine Side.” Denver University Law Review, 86, no. 3 (2009): 633-61.

Coplon, Jon. "White House DJ Battle." Blender, 30 July 2008. https://web.archive. org/web/20080814151724/http://www.blender.com/WhiteHouseDJBattle/ articles/39518.aspx.

Cottle, Michelle. "Wife Lessons: Why Michelle Obama is no Hillary Clinton." New Republic 238, no. 5 (26 March 2008). https://newrepublic.com/article/63047/ wife-lessons.

Crew, Danny O. Presidential Sheet Music: An Illustrated Catalogue of Published Music Associated with the American Presidency and Those who Sought the Office. Jefferson, NC: McFarland, 2001.

Dadas, Caroline E. "Inventing the Election: Civic Participation and Presidential Candidates' Websites." Computers and Composition 25, no. 4 (2008): 416-31. 
Deaville, James. "The Sound of Media Spectacle: Music at the Party Conventions." Music \& Politics 9, no. 2 (2015). DOI: http://dx.doi.org/10.3998/mp.9460447. 0009.205.

Dowd, Maureen. “¿Quién Es Less Macho?” New York Times, 24 February 2008. http://www.nytimes.com/2008/02/24/opinion/24dowd.html? $\mathrm{r}=3 \& \mathrm{scp}=36 \& \mathrm{sq}=$ maureen + dowd\&st=nyt\&oref=slogin\&oref=slogin .

Falcone, Michael. "Obama on 'Obama Girl."” The Caucus (blog). New York Times, 20 August 2007. http://thecaucus.blogs.nytimes.com/2007/08/20/ obama-on-obama-girl/.

Forman, Murray. "Conscious Hip-Hop, Change, and the Obama Era." American Studies Journal 54, no. 3 (2010).

—. "Obama/Time: The President in the Hip Hop Nation." In The Hip Hop \& Obama Reader, edited by Travis L. Gosa and Erik Nielson, 155-75. Oxford: Oxford University Press, 2015.

From Fay To $Z$ (blog). “The Campaign Song Comeback.” Fayetteville Observer, fayobserver.com, 29 October 2008.

Frith, Simon. Sound Effects: Youth, Leisure, and the Politics of Rock 'n' Roll. New York: Pantheon, 1981.

Garman, Brian. "Models of Charity and Spirit: Bruce Springsteen, 9/11, and the War on Terror." In Music in the Post-9/11 World, edited by Jonathan Ritter and J. Martin Daughtry, 71-89. New York: Routledge, 2007.

Gennis, Sadie. "Ice-T Says Rap Music Got Obama Elected President." TV Guide, 13 June 2012. http://www.tvguide.com/news/ice-t-rap-got-obamaelected-president-1048829.aspx.

Gill, Satinder P. "Entrainment and Musicality in the Human System Interface." Artificial Intelligence and Society 21, no. 4 (June 2007): 567-605.

Goff, Keli. Party Crashing: How the Hip-Hop Generation Declared Political Independence. New York: BasicCivitas, 2008.

Goldberg, Bernard. A Slobbering Love Affair: The True (and Pathetic) Story of the Torrid Romance between Barack Obama and the Mainstream Media. Washington, DC: Regnery, 2009.

Gorzelany-Mostak, Dana. “'I've Got a Little List': Spotifying Mitt Romney and Barack Obama in the 2012 U.S. Presidential Election.” Music \& Politics 9, no. 2 (2015). DOI: http://dx.doi.org/10.3998/mp.9460447.0009.202.

Gosa, Travis L. "'The Audacity of Dope': Rap Music, Race, and the Obama Presidency." In The Iconic Obama, 2007-2009: Essays on Media Representations of the Candidate and New President, edited by Nicholas A. Yanes and Derrais Carter, 85-96. Jefferson, NC: McFarland, 2012.

- "Not Another Remix: How Obama Became the First Hip-Hop President." Journal of Popular Music Studies 22, no. 4 (2010): 389-415.

Gosa, Travis L., and Erik Nielson, eds. The Hip Hop \& Obama Reader. Oxford: Oxford University Press, 2015.

- "The State of Hip Hop in the Age of Obama." In The Hip Hop \& Obama Reader, edited by Travis L. Gosa and Erik Nielson, 1-28. Oxford: Oxford University Press, 2015. 
“"There Are No Saviors': An Interview with Kevin Powell." In The Hip Hop \& Obama Reader, edited by Travis L. Gosa and Erik Nielson, 70-87. Oxford: Oxford University Press, 2015.

Hamby, Peter. "Barack Obama Gets Name-Dropped in Hip-Hop." CNN, 17 August 2007. http://www.cnn.com/2007/POLITICS/08/17/obama.hip.hop/index. html.

Harris, Heather E., Kimberly R. Moffitt, and Catherine R. Squires, eds. The Obama Effect: Multidisciplinary Renderings of the 2008 Campaign. Albany: State University of New York Press, 2010.

Hoekstra, Dave. “The Soul of a President.” Chicago Sun-Times, 11 January 2009. Jeffries, Michael P. “The King's English: Obama, Jay Z, and the Science of Code Switching." In The Hip Hop \& Obama Reader, edited by Travis L. Gosa and Erik Nielson, 243-61. Oxford: Oxford University Press, 2015.

- "Obama as Hip-Hop Icon." Epilogue in Thug Life: Race, Gender, and the Meaning of Hip-Hop, 199-206. Chicago: University of Chicago Press, 2011.

—. "Where ya at?' Hip-hop's Political Locations in the Obama Era." In The Cambridge Companion to Hip-Hop, edited by Justin A. Williams, 314-26. Cambridge: Cambridge University Press, 2015.

Jordan, Matthew F. “Obama's iPod: Popular Music and the Perils of Postpolitical Populism.” Popular Communication: The International Journal of Media and Culture 11, no. 2 (2013): 99-115.

Katz, Jackson. Leading Men: Presidential Campaigns and the Politics of Manhood. Northampton, MA: Interlink, 2013.

Kellner, Douglas. "Barack Obama and Celebrity Spectacle." International Journal of Communication 3 (2009): 715-41. https://pages.gseis.ucla.edu/faculty/kellner/ essays/2009_ObamaCelebritySpectacle.pdf.

Kitwana, Bakari. The Hip Hop Generation: Young Blacks and the Crisis in African American Culture. New York: BasicCivitas Books, 2002.

Kitwana, Bakari, and Elizabeth Méndez Berry. "It's Bigger Than Barack: Hip Hop Political Organizing, 2004-2013.” In The Hip Hop \& Obama Reader, edited by Travis L. Gosa and Erik Nielson, 54-69. Oxford: Oxford University Press, 2015.

Klein, Naomi. No Logo: 10th anniversary edition. New York: Picador, 2009.

Lemelle, Anthony J. Black Masculinity and Sexual Politics. New York: Routledge, 2010.

Leibovich, Mark. “The Other Man of the Hour.” Washington Post, 27 July 2004. http://www.washingtonpost.com/wp-dyn/articles/A16606-2004Jul26.html.

Love, Joanna. "Branding a Cool Celebrity President: Advertising with Popular Music in the 2012 Election." Music \& Politics 9, no. 2 (2015). DOI: http://dx.doi.org/ 10.3998/mp.9460447.0009.203.

MacInnes, Gordon. "The Politics of Race: Conservative Indifference Meets Liberal Timidity." In Wrong for All the Right Reasons: How White Liberals Have Been Undone by Race, 13-22. New York: New York University Press, 1996.

Marin, Carol. "Thanks to Hillary for Being a Winner at Heart." Chicago Sun-Times, 11 May 2008. 
Melber, Ari. "Obama Meets Jay-Z in YouTube Mashup Slamming Clinton \& Debate." Huffington Post, 17 April 2008. http://www.huffingtonpost.com/ ari-melber/obama-meets-jay-z-in-yout_b_97342.html.

Meline, Gabe. "Hip-Hop President: How Will Obama’s Presidency Change the Face of Hip-Hop?” Bohemian.com, 31 December 2008. http://www.bohemian.com/ northbay/hip-hop-president/Content?oid=2173004.

Memoli, Mike. "Hillary's 'Testicular Fortitude." NBC News, 30 April 2008. http://firstread.nbcnews.com/'news/2008/04/30/4437744-hillarys-testicularfortitude.

Middleton, Richard. “From Me To You' Popular Music as Message.” In Studying Popular Music, 172-246. Milton Keynes: Open University Press, 1990.

- "Locating the Popular Music Text." In Reading Pop: Approaches to Textual Analysis in Popular Music, edited by Richard Middleton, 1-19. Oxford: Oxford University Press, 2000.

Miller, Claire Cain. "How Obama's Internet Campaign Changed Politics.” Bits (blog). New York Times, 7 November 2008. http://bits.blogs.nytimes.com/2008/ 11/07/how-obamas-internet-campaign-changed-politics/.

Miller, Nick. “The Good Wife.” Sydney Morning Herald, 27 May 2012. http://www. smh.com.au/world/the-good-wife-20120526-1zbs5.html.

Mills, David. "Sister Souljah's Call to Arms: The Rapper Says the Riots Were Payback. Are You Paying Attention?" Washington Post, 13 May 1992. http://www.washingtonpost.com/wp-dyn/content/article/2010/03/ 31/AR2010033101709.html.

Misciagno, Patricia S. "Rethinking the Mythic Presidency." Political Communication 13, no. 3 (1996): 329-44.

Morris, Mitchell. The Persistence of Sentiment: Display and Feeling in Popular Music of the 1970s. Berkeley: University of California Press, 2013.

Murphy, John M. "Inventing Authority: Bill Clinton, Martin Luther King, Jr., and the Orchestration of Rhetorical Traditions." Quarterly Journal of Speech 83, no. 1 (1997): 71-89.

Nielson, Erik. "How Hip-Hop Fell Out of Love with Obama." Guardian, 23 August 2012. http://www.theguardian.com/music/2012/aug/23/why-hip-hopdeserting-obama.

. "My President is Black, My Lambo's Blue': The Obamafication of Rap?" Journal of Popular Music Studies 21, no. 4 (2009): 344-63.

Obama, Barack. "Fatherhood Speech.” Politico, 15 June 2008. http://www.politico. com/news/stories/0608/11094.html

Ogbar, Jeffrey O. G. "Message from the Grassroots: Hip Hop Activism, Millennials, and the Race for the White House." In The Hip Hop \& Obama Reader, edited by Travis L. Gosa and Erik Nielson, 31-53. Oxford: Oxford University Press, 2015.

Ossei-Owusu, Shaun. "'Barack Obama’s Anomalous Relationship with the HipHop Community.” In The Obama Phenomenon: Toward a Multiracial Democracy, edited by Charles P. Henry, Robert L. Allen, and Robert Chrisman, 218-35. Urbana: University of Illinois Press, 2011. 
Parry-Giles, Shawn J., and Trevor Parry-Giles. Constructing Clinton: Hyperreality \& Presidential Image-Making in Postmodern Politics. New York: P. Lang, 2002.

Richmond, Sanford K. "Paint The White House Black!! A Critical Discourse Analysis Look at Hip Hop's Social, Cultural, and Political Influence on the Presidency of Barack Obama." Western Journal of Black Studies 37, no. 4 (Winter 2013): 249-57.

Roberts, Philippa, and Jane Cunningham. "Feminisation of Brands." Marketing, 2 September 2008.

Rose, Tricia. The Hip Hop Wars: What We Talk About When We Talk About Hip Hop-And Why It Matters. New York: BasicCivitas, 2008.

Saffle, Michael. "User-Generated Campaign Music and the 2012 U.S. Presidential Election.” Music \& Politics 9, no. 2 (2015). DOI: http://dx.doi.org/10.3998/mp. 9460447.0009.204.

Scherer, Michael. "Hillary is from Mars, Obama is from Venus." Salon, 12 July 2007. http://www.salon.com/news/feature/2007/07/12/obama_hillary/.

Schoening, Benjamin S., and Eric T. Kasper. Don't Stop Thinking About The Music: The Politics of Songs and Musicians in Presidential Campaigns. Lanham, MD: Lexington, 2012.

Shiver, Kyle-Anne. "Women Voters and the Obama Crush." American Thinker, 11 March 2008. http://www.americanthinker.com/2008/03/women_voters_and_ the_obama_cru.html.

Sikanku, Etse, and Nicholas A. Yanes. “The Modern E Pluribus Unum Man: How Obama Constructed His American Identity from His Global Background." In The Iconic Obama, 2007-2009: Essays on Media Representations of the Candidate and New President, edited by Nicholas A. Yanes and Derrais Carter, 16-27. Jefferson, NC: McFarland, 2012.

Sister Souljah. "Sister Souljah Statement." Rock Out Censorship, [retrieved] 27 June 2012. http://www.theroc.org/roc-mag/textarch/roc-09/roc09-07.htm.

Smith, Ben. "Obama Camp Condemns Song: Ludacris 'Should Be Ashamed." Ben Smith Blog (blog). Politico, 30 July 2008. http://www.politico.com/blogs/ bensmith/0708/Obama_camp_condemns_song_Ludacris_should_be_ashamed. html\#comments.

Smith, Suzanne E. Dancing in the Street: Motown and the Cultural Politics of Detroit. Cambridge, MA: Harvard University Press, 1999.

Solomon, Deborah. “Hip-Hop Guru.” New York Times, 29 April 2007. http://www. nytimes.com/2007/04/29/magazine/29wwlnQ4.t.html?pagewanted=print.

Spence, Lester K. Stare in the Darkness: The Limits of Hip-Hop and Black Politics. Minneapolis: University of Minnesota Press, 2011.

Streeter, Caroline A. "Obama Jungle Fever: Interracial Desire on the Campaign Trail.” In The Iconic Obama, 2007-2009: Essays on Media Representations of the Candidate and New President, edited by Nicholas A. Yanes and Derrais Carter, 167-83. Jefferson, NC: McFarland, 2012.

Sweet, Lynn. “Obama's Selma Speech.” Sweet Blog (blog). Chicago Sun-Times, 5 March 2007. http://blogs.suntimes.com/sweet/2007/03/obamas_selma_speech_ text_as_de.html. 
Talev, Margaret. "Soul of the Obama Campaign Is in the Soundtrack." McClatchy D.C., 31 October 2008. http://www.mcclatchydc.com/2008/10/31/55103/ soul-of-the-obama-campaign-is.html\#.UjHixDn3DfY.

Tapper, Jake, and Jerry Tully. "Rap Mogul Takes On Obama.” ABC News, 16 April 2007. http://abcnews.go.com/GMA/story?id=3045077.

Vernallis, Carol. "Audiovisual Change: Viral Web Media and the Obama Campaign." Cinema Journal 50, no. 4 (Summer 2011): 73-97.

Walters, Ron. "Barack Obama and the Politics of Blackness." Journal of Black Studies 38, no. 1 (September 2007): 7-29.

Warner, Judith. "Sometimes a President Is Just a President." Opinionator (blog). New York Times, 5 February 2009. http://opinionator.blogs.nytimes.com/2009/ 02/05/sometimes-a-president-is-just-a-president/.

Watkins, S. Craig. Hip Hop Matters: Politics, Pop Culture, and the Struggle for the Soul of a Movement. Boston: Beacon, 2005.

Wenner, Jann S. “A Conversation with Barack Obama.” Rolling Stone, 1056/1057, 10 July-24 July 2008. http://www.jannswenner.com/Archives/Barack'Obama. aspx.

Wicke, Peter. Rock Music: Culture, Aesthetics, and Sociology. Translated by Rachel Fogg. Cambridge: Cambridge University Press, 1990.

Wilson, Marie. "Leading Like a Girl: For Men Only?" Huffington Post, 15 April 2008. http://www.huffingtonpost.com/marie-wilson/leading-like-a-girl-for-m b_96753.html.

Zeleny, Jeff. “Long By Obama's Side, An Adviser Fills a Role That Exceeds His Title.” New York Times, 26 October 2008. http://www.nytimes.com/2008/10/27/ us/politics/27axelrod.html?_r=1.

\section{Media}

“Barack Gets That Dirt off His Shoulders.” 17 April 2008. Video Clip. YouTube. http://www.youtube.com/watch?v=yel8IjOAdSc.

"Barack Obama on Ellen." 30 October 2007. Video Clip. YouTube. https://www. youtube.com/watch?v=RsWpvkLCvu4.

“Crush on Obama.” 13 June 2007. Video Clip. YouTube. http://www.youtube.com/ watch?v=wKsoXHYICqU.

"Doktor Love ft. Stevie Wonder-Barack Obama Song." 3 August 2008. Video Clip. YouTube. http://www.youtube.com/watch?v=guCcgfVUeZk.

“Obama Dirt off Your Shoulder Remix.” 18 April 2008. Video Clip. YouTube (no longer available).

“Obama Gets That Dirt off His Shoulder." 17 April 2008. Video Clip. YouTube. http://www.youtube.com/watch?v=kzXcNgCr0nk.

"Rap Artist's Response to Clinton Remarks." 16 June 1992. Video Clip. C-SPAN Video Library. http://www.c-spanvideo.org/program/26613-1.

SNL skit. Saturday Night Live. Season 33. Episode 5. 2008.

"Stevie Wonder Sings Obama Song." 23 December 2008. Video Clip. YouTube. http://www.youtube.com/watch?v=ZN3caKwHlK4\&feature=related. 
“USA President Barack Obama Opinion on Hip-Hop \& Rap 2008” [Barack Obama, interview with Jeff Johnson on BET's political special "What's in It For Us?" aired 8 January 2008]. 3 February 2008. Video Clip. YouTube. http://www.youtube. com/watch?v=pFSVG7jRp_g.

Wonder, Stevie. Signed, Sealed \& Delivered. Tamla TS304, 1970, LP.

"YES WE CAN-New Approaches_Entertainment-EMMY WINNER." 3 June 2008. Video Clip. YouTube. http://www.youtube.com/watch?v=SsV2O4fCgjk. Yes We Can: Voices of a Grassroots Movement. Hidden Beach, B001IF269Y, 2008, CD. 